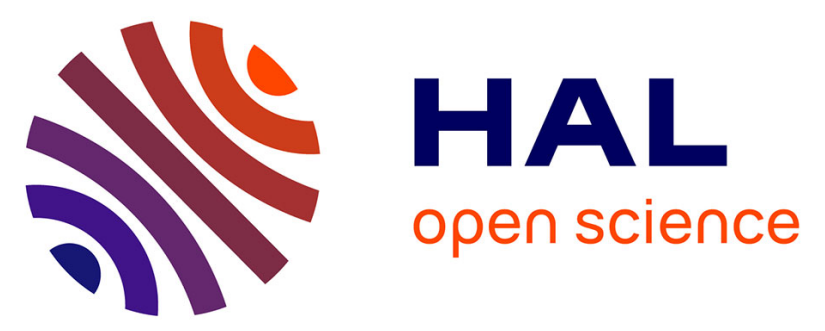

\title{
A new phylogeny and environmental DNA insight into paramyxids: an increasingly important but enigmatic clade of protistan parasites of marine invertebrates
}

Georgia M. Ward, Martyn Bennett, Kelly Bateman, Grant D. Stentiford, Rose

Kerr, Stephen W. Feist, Suzanne T. Williams, Cedric Berney, David Bass

\section{To cite this version:}

Georgia M. Ward, Martyn Bennett, Kelly Bateman, Grant D. Stentiford, Rose Kerr, et al.. A new phylogeny and environmental DNA insight into paramyxids: an increasingly important but enigmatic clade of protistan parasites of marine invertebrates. International Journal for Parasitology, 2016, 46 (10), pp.605-619. 10.1016/j.ijpara.2016.04.010 . hal-01346477

\section{HAL Id: hal-01346477 \\ https://hal.sorbonne-universite.fr/hal-01346477}

Submitted on 19 Jul 2016

HAL is a multi-disciplinary open access archive for the deposit and dissemination of scientific research documents, whether they are published or not. The documents may come from teaching and research institutions in France or abroad, or from public or private research centers.
L'archive ouverte pluridisciplinaire HAL, est destinée au dépôt et à la diffusion de documents scientifiques de niveau recherche, publiés ou non, émanant des établissements d'enseignement et de recherche français ou étrangers, des laboratoires publics ou privés. 
1 A new phylogeny and environmental DNA insight into paramyxids: an increasingly

2 important but enigmatic clade of protistan parasites of marine invertebrates $\star$

3 Georgia M Ward ${ }^{\mathrm{a}, \mathrm{b}}$, Martyn Bennett ${ }^{\mathrm{a}, \mathrm{c}}$, Kelly Bateman ${ }^{\mathrm{a}}$, Grant D Stentiford ${ }^{\mathrm{a}, \mathrm{c}}$, Rose Kerr ${ }^{\mathrm{a}}$, Stephen

4 W Feist ${ }^{a}$, Suzanne T Williams ${ }^{b}$, Cedric Berney ${ }^{d}$, David Bass ${ }^{a, b, *}$

5

6

7

${ }^{a}$ Centre for Environment, Fisheries, and Aquaculture Science (Cefas), Barrack Road, The Nothe,

9 Weymouth, Dorset DT4 8UB, UK

$10{ }^{\mathrm{b}}$ Department of Life Sciences, The Natural History Museum, London SW7 5BD, UK

$11{ }^{c}$ School of Biosciences, University of Exeter, Stocker Road, Exeter EX4 4QD, UK

12 EPEP team, UMR 7144, CNRS \& Sorbonne Universités UPMC Paris 06, Station

13 Biologique de Roscoff, Place Georges Teissier, 29680 Roscoff, France

14

$16{ }^{*}$ Corresponding author. David Bass, Tel.: +44 1305206752.

17 E-mail address: david.bass@cefas.co.uk accession numbers $\underline{\text { KX259318-KX259327. }}$ 


\section{Abstract}

Paramyxida is an order of rhizarian protists that parasitise marine molluscs, annelids and crustaceans. They include notifiable pathogens (Marteilia spp.) of bivalves and other taxa of economic significance for shellfish production. The diversity of paramyxids is poorly known, particularly outside of commercially important hosts, and their phylogenetic position is unclear due to their extremely divergent $18 \mathrm{~S}$ rDNA sequences. However, novel paramyxean lineages are increasingly being detected in a wide range of invertebrate hosts, and interest in the group is growing, marked by the first 'Paramyxean Working Group' Meeting held in Spain in February 2015. We review the diversity, host affiliations, and geographical ranges of all known paramyxids, present a comprehensive phylogeny of the order and clarify its taxonomy. Our phylogenetic analyses confirm the separate status of four genera: Paramarteilia, Marteilioides, Paramyxa and Marteilia. Further, as including M. granula in Marteilia would make the genus paraphyletic we suggest transferring this species to a new genus, Eomarteilia. We present sequence data for Paramyxa nephtys comb. n., a parasite of polychaete worms, providing morphological data for a clade of otherwise environmental sequences, sister to Paramarteilia. Light and electron microscopy analyses show strong similarities with both Paramyxa and Paramyxoides, and we further discuss the validity of those two genera. We provide histological and electron microscopic data for Paramarteilia orchestiae, the type species of that genus originally described from the amphipod Orchestia; in situ hybridisation shows that Paramarteilia also infects crab species. We present, to our knowledge, the first known results of a paramyxid-specific environmental DNA survey of environmental (filtered water, sediment, etc.) and organismally-derived samples, revealing new lineages and showing that paramyxids are associated with a wider range of hosts and habitat types than previously known. On the basis of our new phylogeny we propose phylogenetic hypotheses for evolution of lifecycle and infectivity traits observed in different paramyxid genera.

Keywords: Paramyxida; Paramyxa; Marteilia; Marteilioides; Paramarteilia; Eomarteilia; eDNA; 18S rDNA phylogeny 


\section{Introduction}

Paramyxida (Rhizaria, Ascetosporea) are related to haplosporidians, paradinids and mikrocytids (Bass et al., 2009; Hartikainen et al., 2014a,b), although the evolutionary relationships among the five ascetosporean orders are currently unresolved. Paramyxids are apparently exclusively parasites of marine invertebrates - annelids, crustaceans and molluscs. Five genera have been recognised: Marteilia, Paramarteilia, Marteilioides, Paramyxa and Paramyxoides. However, Feist et al. (2009) suggested that Marteilioides and Paramyxoides should be suppressed and that Marteilioides chungmuensis be reassigned to Marteilia, Marteilioides branchialis to Paramarteilia, and Paramyxoides to Paramyxa. One of the aims of the present study was to assess this recommendation by applying the first molecular phylogenetic approach to the group as a whole.

Paramyxids are increasingly recognised as pathogens causing economically significant mortalities of bivalves. The best known of these are marteiliosis/Aber disease in the European oyster Ostrea edulis and QX disease in the Sydney rock oyster Saccostrea glomerata, caused by Marteilia refringens and Marteilia sydneyi, respectively (Perkins and Wolf, 1976; Berthe et al., 2004; both species are listed as notifiable to the World Organisation for Animal Health (World Organisation for Animal Health (OIE) http://www.oie.int/en/international-standard-setting/aquaticcode/ (2015). Other significant bivalve diseases are caused by Marteilia cochillia in cockles (Carrasco et al., 2012, 2013), Marteilioides chungmuensis in Crassostrea gigas in Korea and Japan (Comps et al., 1986; Itoh et al., 2003), and Marteilia granula in the clam Venerupis philippinarum in Japan (Itoh et al., 2014).

Paramyxids in crustaceans include Paramarteilia canceri, which causes diseases of the edible/brown crab Cancer pagurus (Feist et al., 2009), and Paramarteilia orchestiae in amphipods, where it has been investigated in relation to modification of their sexual status (Ginsburger-Vogel 1991; Short et al., 2012a,b). However, beyond these very few examples there are so far no other reports of paramyxids causing disease in crustaceans, although more recently copepods have been shown to be vectors in the lifecycle of M. refringens (Carrasco et al., 2007; Arzul et al., 2014). 
Polychaetes are similarly understudied as potential hosts of paramyxids. Adlard and Nolan

77 (2015) recently demonstrated that $M$. sydneyi cycles through both the polychaete Nephtys australis and the oyster S. glomerata, providing another example of the complexity of at least some paramyxid lifecycles. Otherwise the only known annelid-infecting paramyxid is Paramyxa, of which the only described species, Paramyxa paradoxa, was first described in a polychaete larva from Banyuls-sur-Mer on the Mediterranean French coast by Chatton (1911). No similar organisms were reported until a paramyxid parasite of the polychaete Nephtys caeca was described by Larsson and Køie (2005) as Paramyxoides nephtys, distinguished from P. paradoxa on the basis of spore shape and cytology. However, Feist et al. (2009) considered that the characters used to distinguish these two genera were taxonomically invalid and transferred Paramyxoides to Paramyxa.

Paramyxids are also commonly referred to as paramyxeans. This class/order discrepancy deserves some explanation, to clarify the actual classification of the group and to ground its nomenclature in a robust phylogenetic context, which is an important aim of this study. Like many enigmatic micro-eukaryote groups, paramyxid taxonomy has been historically unstable, partly due to high levels of phenotypic conservation and convergence commonly seen in protists, particularly parasites (Boenigk et al., 2012; Hartikainen et al., 2014b; Neuhauser et al., 2014; Poulin and Randhawa, 2015). The presence of haplosporosome-like bodies provided early evidence that Marteilia and Paramarteilia were related to haplosporidans (Perkins, 1979), and ultrastructural characteristics supported a relationship between these genera and the first described genus eventually assigned to paramyxids, Paramyxa (Chatton, 1911; Desportes and Lom, 1981). Marteilia and Paramarteilia were described later, in the 1970s (Perkins, 1976; Perkins and Wolf, 1976; Desportes and Ginsburger-Vogel, 1977; Ginsburger-Vogel and Desportes, 1979), as detailed in Desportes and Perkins (1990) and Feist et al. (2009). All three genera are distinguished from haplosporidans by the production of variable numbers of daughter cells endogenously formed within a primary amoeboid stem cell, leading to their characteristic 'cell within cell' development. This group has been treated as a class (Paramyxidea Levine, 1980), phylum (Paramyxea Desportes and Perkins, 1990), and most recently as the order Paramyxida in Bass et al. (2009), 
104 which is both the original and most stable taxonomy, concordant with both molecular and 105 morphological analyses (Cavalier-Smith and Chao, 2003a,b; Bass et al., 2009; Feist et al., 2009).

106 Environmental DNA (eDNA) sequencing studies (i.e. generating and sequencing PCR 107 amplicons or metagenetic fragments from DNA/RNA extracted from environmental samples to 108 assess their biodiversity) are beginning to reveal high levels of diversity within groups of known 109 parasites (Bass et al., 2009, 2015; Hartikainen et al., 2014a,b), providing powerful insights into 110 parasite lifecycles, environmental reservoirs and transmission routes, and previously unknown 111 parasitic lineages. These approaches are seen as increasingly important for disease monitoring 112 and prediction, and policy issues, as described in Stentiford et al. (2014) and Bass et al. (2015).

113 Paramyxid 18S rRNA genes are phylogenetically divergent and therefore usually missed in

114 broadly-targeted 18 S sequencing surveys (Bass et al., 2015). In such cases PCR primers

115 designed specifically for the group under study can be very valuable (Hartikainen et al., 2014a,b).

116 One aim of this study was to design and optimise such a primer set to better understand

117 paramyxid diversity and phylogeny.

As well as generating new eDNA-based sequences as described above, we also analyse

119 all available paramyxid 18S rDNA sequences, providing a comprehensive paramyxid phylogenetic

120 tree, in order to rationalise paramyxid nomenclature and determine their evolutionary relationships.

121 We show that Marteilia, Paramarteilia and Marteilioides form highly distinct and robustly supported 122 phylogenetic clades, confirming their validity as separate genera, and that all three genera form a

123 robustly supported clade that also includes M. granula (recently described by Itoh et al., 2014), and

124 uncharacterised environmental sequences, confirming the monophyly of the order Paramyxida. 
For invertebrates, 150 mussels, Mytilus edulis, were collected from the River Tamar

129

130

131

132

133

134

135

136

137

138

140

141

142

143

144

145

146

147

148

149

150

151

152

153

154

155

156

estuary mouth near Cremyll Ferry, Devon, UK in June and July 2013. The June individuals were incubated in sterile artificial sea water (ASW; Culture Collection of Algae and Protozoa (CCAP) recipe (www.ccap.ac.uk/media/documents/ASW.pdf)) in sets of 10 individuals (clustered according to sampling proximity) for $1 \mathrm{~h}$. Post-incubation, $50-100 \mathrm{ml}$ of water were syringe-filtered through Whatman GF/F filters (GE Healthcare, USA) and filters subsequently fixed in $100 \%$ moleculargrade ethanol. A further 150 individuals of $M$. edulis and 222 Ostrea edulis were similarly collected from a nearby site, Jupiter Point (River Lynher, Tamar Estuary, UK), in September 2015. All bivalves were dissected and tissue cross-sections including digestive gland and mantle were fixed in Davidson's Solution for histology, glutaraldehyde for electron microscopy (EM), and 100\% ethanol (June samples) or flash frozen in liquid nitrogen (July samples) for molecular analyses. Other invertebrates (polychaetes, amphipods, shrimp, barnacles) were also sampled from sediments and under rocks in the mussel sampling areas. Animals were kept intact and preserved in $100 \%$ molecular ethanol at $-20^{\circ} \mathrm{C}$ until DNA extraction. Amphipods, Orchestia gammarellus, were collected at low tide in the intertidal zone above the high water mark at Castle Cove, Weymouth, England (50³5' 45.6”' N, $2^{\circ} 27^{\prime} 36^{\prime \prime}$ W; $n=178$ ) between September 2014 and February 2015 and in the Gann Estuary, Dale, Wales $(n=197)$ during November 2014. For O. gammarellus, morphological identity was confirmed, length was measured using calipers, sex was determined and any external abnormalities, i.e. lost limbs or notable markings, were recorded. The O. gammarellus were anaesthetised using clove oil (Eugenol $80-90 \%$ ) at a dilution of $0.2 \mu \mathrm{l} / \mathrm{ml}$ of seawater and were transversely sectioned into three using a stereomicroscope (Leica M125, Leica Microsystems, Germany). One section was placed in 100\% ethanol for molecular work; the second section was placed in a $2.5 \%$ glutaraldehyde $0.2 \mathrm{M}$ sodium cacodylate buffer for transmission electron microscopy (TEM) and the final section was placed into a cassette in Davidson's Sea Water Fixative for $24 \mathrm{~h}$ for histopathology and in situ hybridization (ISH).

Edible crabs, Cancer pagurus, were captured in baited traps from the commercial fishery in Weymouth Bay area in January 2004. A total of 30 crabs were transported back to the Weymouth laboratory, where they were anaesthetised on ice for $30 \mathrm{~min}$ before dissection. Hepatopancreas, heart, gill, muscle and gonad tissues were fixed in Davidson's sea water fixative for histology and 
157 hepatopancreas and gonad samples were fixed in $2.5 \%$ glutaraldehyde in $0.1 \mathrm{M}$ sodium

158

159

160

161

162

163

164

165

166

167

168

169

170

171

172

173

174

175

176

177

178

179

180

181

182

183

184

cacodylate buffer for EM.

Spider crabs, Maja squinado, were captured using a Granton trawl on board the Cefas

Endeavour from the Cardigan Bay area, Wales, in July 2008. As for edible crabs, 30 spider crabs

were anaesthetised on ice for 30 min before dissection; hepatopancreas, heart, gill, muscle and

gonad tissues were fixed in Davidson's sea water fixative for histology and hepatopancreas

samples were fixed in $2.5 \%$ glutaraldehyde in $0.1 \mathrm{M}$ sodium cacodylate buffer for $\mathrm{EM}$.

Polychaete worms (100 specimens, mostly $N$. caeca) were collected from the tidal, brackish Fleet lagoon, Weymouth, Dorset, UK (10-30 ppt salinity) on 15 May 2015. Each worm was dissected into three sections in the field and fixed for molecular analyses, histology and EM.

For environmental samples, $150 \mathrm{~L}$ water samples collected at three sites in the Tamar estuary: Cremyll Ferry, Wilcove, and Neal's Point, were passed serially though $50 \mu \mathrm{m}$ and $20 \mu \mathrm{m}$ meshes. Material collected on the meshes (filtrand) was transferred to $2 \mathrm{ml}$ cryotubes and fixed in $100 \%$ ethanol. A $50 \mathrm{~L}$ aliquot of water from each site was kept cool and in the dark and transported to the laboratory within $24 \mathrm{~h}$, where aliquots were filtered under pressure onto $142 \mathrm{~mm}, 0.45 \mu \mathrm{m}$ cellulose acetate filters (Sartorius, Germany) and immediately stored at $-80^{\circ} \mathrm{C}$. Littoral sediment samples $(0.5-1 \mathrm{~g})$, from the areas in which mussels were sampled, were taken from the Cremyll site and fixed in $100 \%$ ethanol. Water and sediment samples were collected using the same protocols from Newton's Cove and the Fleet lagoon in June and October 2011, and April 2012.

Filtered freshwater and littoral marine water were similarly sampled (but without the $0.45 \mu \mathrm{m}$ filtering step) and benthic sediments from sites in the Western Cape, South Africa 10x water samples, 14x sediment and sand samples), Sabah, Borneo, Malaysia in December 2011 (38x water samples) and various sites in Florida, USA in June 2014 (47x water samples, 34x invertebrate incubations (as for $M$. edulis incubations, above). Water from shrimp hatchery tanks at the Borneo Marine Research Institute (University of Malaysia, Sabah) was sampled (5x) also as for M. edulis incubations.

\subsection{Sample processing and DNA extraction}


Sediment and $50 \mu \mathrm{m}$ and $20 \mu \mathrm{m}$ fraction filtrand samples were freeze-dried at $-40^{\circ} \mathrm{C}$ until

186

187

188

189

190

192

193

194

195

196

197

198

199

200

201

202 dry. DNA was extracted from these and the $0.45 \mu \mathrm{m}$ fraction filtrand using the PowerSoil DNA Isolation Kit (MoBio Laboratories, Carlsbad, CA, USA). DNA was extracted from invertebrate (apart from amphipod) tissue from all sites using the DNEasy Blood and Tissue Kit (Qiagen, Germany). Flash frozen mussel tissue was defrosted into RNAlater (Qiagen) before DNA extraction using the 96-well DNEasy Bood and Tissue Kit (Qiagen).

For the amphipods, the $100 \%$ ethanol-preserved samples were suspended in a solution of Lifton's buffer (Sucrose 2.3\% w/v, $1 \mathrm{M}$ Tris pH 8.0, SDS, $0.5 \mathrm{M}$ EDTA pH 8.0) containing

Proteinase $\mathrm{K}(100 \mathrm{mg} / \mathrm{ml})$. Following incubation overnight at $55^{\circ} \mathrm{C}$, DNA was extracted using a phenol chloroform extraction method with ethanol precipitation (Nishiguchi et al., 2002). The resulting DNA was suspended in $40 \mu \mathrm{l}$ of water and the DNA concentrations of each sample $(\mathrm{ng} / \mu \mathrm{l})$ were quantified via spectrophotometry (NanoDrop ND-1000) and the QuantiFluor®DS-DNA system and Quantus Fluorimeter (Promega, UK) by following the kit manufacturer's instructions. Filters from invertebrate incubation samples were freeze-dried at $-40^{\circ} \mathrm{C}$ for $2 \mathrm{~h}$ to remove ethanol. Dried filters were subsequently kept on ice and cut into small pieces using sterile scissors, prior to DNA extraction using the DNEasy Blood and Tissue Kit (Qiagen).

\section{3. $P C R$ and sequencing}

A nested primer set targeting regions $V 7$ and $V 8$ of the paramyxid 18S rRNA gene was designed, based on all available paramyxid sequence data in June 2013. The first round PCR used primers Para1+fN (5'- GCG AGG GGT AAA ATC TGA T -3') and ParaGenrDB (5'- GTG TAC AAA GGA CAG GGA CT-3'). Second round PCR used primers Para3+fN (5'- GGC TTC TGG GAG ATT ACG G -3') and Para2+rN (5'- TCG ATC CCR ACT GRG CC-3') (primer set A). All PCRs were conducted in $20 \mu \mathrm{l}$ final volumes with $1 \mu \mathrm{l}$ of template DNA and a final concentration of 0.5 $\mu \mathrm{M}$ of each primer, $0.4 \mathrm{mM}$ dNTPs, $2.5 \mathrm{mM}$ of $\mathrm{MgCl}_{2}$, 1 x Promega Green Buffer and $0.5 \mathrm{U}$ of Promega GoTaq. Cycling conditions for first round PCR consisted of a 3 min denaturation at $94^{\circ} \mathrm{C}$, followed by 42 cycles of $95^{\circ} \mathrm{C}$ for $30 \mathrm{~s}, 67^{\circ} \mathrm{C}$ annealing for $1 \mathrm{~min}$ and $72{ }^{\circ} \mathrm{C}$ for $1 \mathrm{~min}$. Amplicons were extended by final incubation at $72^{\circ} \mathrm{C}$ for $5 \mathrm{~min}$ and stored at $4^{\circ} \mathrm{C}$. Second round PCR used 1 
$213 \mu \mathrm{I}$ of first round product as template DNA, and the cycling conditions were altered to an annealing

214 temperature of $62^{\circ} \mathrm{C}$. These primers were used to screen environmental and invertebrate

215 tissue/incubation samples from the Newton's Cove, Fleet, Tamar estuary, Florida, and Borneo,

216 except those detailed in the following paragraph.

217 Following the publication of sequence data for 'Marteilia' granula (Itoh et al., 2014) primer

218 set A was modified to include this sequence type (primer set B). The resulting hemi-nested PCR

219 protocol used Para1fGW (5'- GGG CGA GGG GTA AAA TCT -3') and ParaGENrGW (5'- GTG

220 TAC AAA GGR CAG GGA CT -3') (first round), followed by Para3fGW (5'- GGC TTY TGG GAG

221 AKT ACG GC -3') and ParaGENrGW (second round). PCR mixtures were prepared as above.

222 Cycling conditions consisted of a 5 min denaturation at $95^{\circ} \mathrm{C}$, followed by 30 cycles of $95^{\circ} \mathrm{C}$ for 1

$223 \min , 58^{\circ} \mathrm{C}$ annealing for $1 \mathrm{~min}$ and $72^{\circ} \mathrm{C}$ extension for $1 \mathrm{~min}$. Amplicons were extended by a final

224 incubation at $72^{\circ} \mathrm{C}$ for $10 \mathrm{~min}$ and stored at $4^{\circ} \mathrm{C}$. The same cycling conditions were used for both

225 rounds of the hemi-nested PCR. These primers were used to screen the polychaete worms from

226 the Fleet lagoon in May 2015, O. edulis and M. edulis tissues from Jupiter Point (Tamar, UK)

227 collected in September 2015, and eDNA from South Africa. A panel of samples comprising

228 representatives from each sample set screened using primer set A was screened with primer set B

229 to test for additional diversity not detected by primer set A. No differences between the diversity

230 detected and frequency of paramyxid-positive PCRs were detected in these samples.

Fragments were visualised on $1.5 \%$ agarose gels stained with GelRed. Amplicons were

232 Sanger sequenced in one direction using primer Para3+fN or Para3fGW. Where direct sequencing

233 produced a mixed product (Cremyll sediment, Wilcove water samples), amplicons were pooled

234 from all PCR-positive samples and clone libraries were prepared using the Stratagene cloning kit

235 (Agilent Technologies, Santa Clara, CA, USA). Eight clones from each sample were sequenced in 236 one direction using the M13R primer. 
All available paramyxid sequences were downloaded from National Center for

240 Biotechnology Information, (USA) GenBank, including Blastn searches to identify uncharacterised

241 (including environmental) sequences related to known taxa. These were aligned with sequences

242 generated in this study using Mafft version 7, e-ins-i algorithm (Katoh and Standley, 2013). The

243 resulting alignment, (47 sequences, including haplosporidian outgroup; 1812 positions analysed)

244 was refined manually and analysed using Maximum Likelihood (ML) in RAxML BlackBox version 8

245 (Stamatakis, 2014) (Generalized time-reversible (GTR) model with CAT approximation (all

246 parameters estimated from the data); an average of 10,000 bootstrap values was mapped onto the

247 tree with the highest likelihood value). A Bayesian consensus tree was constructed using MrBayes

248 v 3.2.5 (Ronquist et al., 2012). Two separate $\mathrm{MC}^{3}$ runs with randomly generated starting trees

249 were carried out for 2 million generations each with one cold and three heated chains. The

250 evolutionary model applied included a GTR substitution matrix, a four-category autocorrelated

251 gamma correction and the covarion model. All parameters were estimated from the data. Trees

252 were sampled every 1,000 generations. The first 500,000 generations were discarded as burn-in

253 (trees sampled before the likelihood plots reached stationarity) and a consensus tree was

254 constructed from the remaining sample. Sequences generated by this study are available from

255 NCBI GenBank (Accession numbers KX259318-KX259327), and are indicated in Fig. 1.

Following $24 \mathrm{~h}$ fixation, samples were suspended in $70 \%$ industrial methylated spirits (IMS) before being dehydrated and infiltrated with paraffin wax using a Vacuum Infiltration processor (Peloris, Leica Microsystems UK). Wax embedded samples were trimmed along the sagittal plane using a rotary microtome (Shandon Finesse 325, Thermo Fisher, UK) to expose tissue. Once trimmed, sections (3-4 $\mu \mathrm{m}$ thick) were mounted onto glass slides and stained using H\&E in an auto-stainer (Surgipath, UK) and then cover-slipped (ClearVue, Thermo Fisher, UK). Screening of

264 samples for pathogens was performed using a Nikon Eclipse E800 light microscope (Nikon, UK).

265 Digital images and measurements were captured using the integrated LEICA ${ }^{\mathrm{TM}}$ (Leica, UK) camera 266 and LuciaG software (Nikon). 
ISH was carried out on O. gammarellus slides to localise $P$. orchestiae, and $C$. pagurus, and M. squinado slides for Paramarteilia. Probes were generated by PCR using Paramarteiliaspecific primers Porchest298f (5'-CTG ATG AGC CTG GCA AGA CCA C-3') and Porchest396r (5'TGG GGC ACA CCG ATA CTG GG-3'), producing a 98 bp amplicon specific to the clade marked

271 'Paramarteilia' on Fig. 1. The process was also carried out on $N$. caeca slides for Paramyxa nephtys; Paramyxa-specific probes were generated using primers Paramyxa240f (5'- AGC AGA CCA ATC GCT CGA C -3') and Paramyxa449r (5'- GAC TCA TTC GTG GCG CGT TT -3'),

274 producing a 209 bp amplicon. In each case probes were digoxigenin (DIG)-labelled using 275 digoxigenin-11-dUTP in PCRs of $100 \mu$ volume with a final concentration of $1 x$ Promega colourless buffer, $2.5 \mathrm{mM} \mathrm{MgCl}, 20 \mu \mathrm{M}$ PCR DIG labelling mix (Roche, Switzerland), $0.5 \mu \mathrm{M}$ of each primer, $0.5 \mathrm{U}$ of Promega GoTaq and $6 \mu$ of template DNA. Amplifications were performed on a Peltier PTC-225 thermal cycler. Cycling conditions consisted of a 5 min denaturation at $94^{\circ} \mathrm{C}$, followed by 40 cycles of $95^{\circ} \mathrm{C}$ for $30 \mathrm{~s}$, taxon-specific annealing temperature for $45 \mathrm{~s}\left(60^{\circ} \mathrm{C}\right.$ for

280 Paramarteilia; $55^{\circ} \mathrm{C}$ for Paramyxa), and $72^{\circ} \mathrm{C}$ for $1 \mathrm{~min}$. Amplicons were extended by final 281 incubation at $72^{\circ} \mathrm{C}$ for $5 \mathrm{~min}$ and stored at $4^{\circ} \mathrm{C}$. Tissue sections $(4 \mu \mathrm{m}$ thick) from histologically282 positive individuals were mounted on Poly- $L$ lysine slides. These were deparaffinised, rehydrated 283 and then treated with Proteinase $\mathrm{K}$ solution $(10 \mathrm{mg} / \mathrm{ml})$ for $30 \mathrm{~min}$ at $37^{\circ} \mathrm{C}$ in a humid chamber. 284 Proteolysis was terminated by incubating the slides in $100 \%$ industrial methylated spirits for 5 min and rinsing slides with $2 x$ SSC buffer for $5 \mathrm{~min}$ at room temperature. Sections were overlaid with a

286 hybridization solution (4 x SSC buffer, 50\% formamide, 1 x Denhardt's solution, $10 \%$ dextran sulfate, $250 \mu \mathrm{g} / \mathrm{ml}$ Yeast tRNA) containing the probe DNA (50:50 v/v). Slides were heated to $95^{\circ} \mathrm{C}$ for 5 min and hybridized overnight at $42^{\circ} \mathrm{C}$. After hybridization, sections were washed with $1 \times$ SSC buffer and $0.5 \times$ SSC buffer for 15 min at $42{ }^{\circ} \mathrm{C}$. Slides were blocked with $6 \%$ non-fat milk in Tris buffer $(\mathrm{pH} 7.5)$ for $1 \mathrm{~h}$ at room temperature. The reactions were then developed with anti-DIG 291 antibody conjugated with an alkaline phosphatase, nitroblue tetrazolium (NBT) and 5-bromo-4-

292 chloro-3-indoylphosphate (X-phos). The sections were counterstained with Nuclear Fast Red and 293 examined under light microscopy. Negative controls lacked the DIG-labelled probe in the 294 hybridization buffer. 
296

297

298

299

300

301

302

303

304

305

306

307

308

309

311

312

313

314

\subsection{Transmission Electron Microscopy (TEM)}

Selected parasite-positive animals were removed from glutaraldehyde and sectioned into 1 $\mathrm{mm}^{3}$ tissue blocks. The samples were fixed in $2.5 \%$ gluteraldehyde in $0.1 \mathrm{M}$ sodium cacodylate buffer $(\mathrm{pH} 7.4)$ for $2 \mathrm{~h}$ and post-fixed by rinsing them in $1 \%$ osmium tetroxide in $0.1 \mathrm{M}$ sodium cacodylate buffer $(1 \mathrm{~h})$. The samples received two rinses in $0.2 \mathrm{M}$ sodium cacodylate buffer (10 min) before being dehydrated through a graded acetone series $(10 \%, 30 \%, 50 \%, 70 \%, 90 \%$ and $100 \%$ ) with $10 \mathrm{~min}$ in each solution. Samples were then infiltrated by Agar 100 epoxy resin (Agar Scientific, UK) Agar 100 pre-mix kit medium) and embedded by polymerising the samples at $60^{\circ} \mathrm{C}$ overnight. Semi-thin sections $(0.5 \mu \mathrm{m}-2 \mu \mathrm{m})$ were taken from resulting blocks and stained with Toluidine Blue. Stained semi-thin sections were surveyed using a light microscope to identify target regions, and 70-90 $\mathrm{nm}$ ultra-thin sections of these regions were mounted on uncoated copper grids. Finally, the samples were stained with $2 \%$ uranyl acetate solution followed by Reynolds' Lead Citrate (Reynolds, 1963) before being examined using a transmission electron microscope (JEOL JEM 1210, Japan). Digital images were obtained using Gatan Digital Micrograph ${ }^{\mathrm{TM}}$ software with a Gatan Erlangshen ES500W camera. All raw images files are accessible via Mendeley Data: http://dx.doi.org/10.17632/jvphfxw32t.1.

\section{Results}

\subsection{Paramyxid diversity}

Table 1 summarises all paramyxid genera and species for which 18S rDNA sequence data are available in public databases and/or are robustly identified morphologically (as a result of our literature survey), indicating their known host ranges and geographical distributions. The new data generated by the study are also included in this table.

\subsection{Paramyxid $18 S$ rDNA phylogeny}


Bayesian and $\mathrm{ML}$ analyses of all currently known and newly generated paramyxid $18 \mathrm{~S}$ rDNA data shows that the genera Marteilia, Paramarteilia and Marteilioides, and a newly

323 sequenced parasite of $N$. caeca and other polychaetes, group separately from each other, each in 324 robustly supported clades of congeners and/or environmental sequences (Fig. 1A). Eomarteilia 325 (previously Marteilia) granula does not branch with other Marteilia spp, but is sister to all other 326 known paramyxeans with moderate to strong support in $\mathrm{ML}$ and Bayesian analyses with maximal 327 taxon sampling (Fig. 1A). We therefore re-assign this to the new genus Eomarteilia. Two lineages 328 exclusively comprising environmental sequences are described in section 3.4. Although diversity 329 within each of the genus clades is not high, some other relevant points arise from the phylogenetic 330 analyses.

\subsubsection{Marteilioides}

The Marteilioides clade has two distinct, known sister lineages, one ( $M$. chungmuensis)

334 from two Crassostrea spp. (C. gigas and C. ariakensis from Japan and South Korea; a total of five 335 sequences in GenBank), and the other (undescribed Marteilioides sp.) from two independent 336 studies in the Manila clam Ruditapes philippinarum (two GenBank sequences) (Yanin et al., 2013, 337 first observed by Lee et al., 2001).

340 The Marteilia clade contains sequences which cluster in rough agreement with their geographical provenance: $M$. refringens and $M$. cochillia, sampled on many independent occasions

342 from Europe (Kerr et al., unpublished data) and M. octospora from Spain (Ruiz et al., 2016) share

343 very similar 18 S sequences, and form a strongly supported clade with the highly distinct $M$.

344 sydneyi sequence from Saccostrea glomerata from Queensland, Australia, 'Marteilia sp. MC' from 345 Ruditapes philippinarum in South Korea (Kang et al., unpublished data; sequence has GenBank accession number $\underline{\mathbf{A B} 823743}$ ), and another distinct sequence derived from a shrimp hatchery tank 
347 at the Borneo Marine Research Institute. As noted above, M. granula does not belong to this clade.

348 A further sequence (not in GenBank) from Mytilus sp. from China was manually copied from Wang

349 et al. (2012) and aligned with the Marteilia sequences in Fig. 1A. This is presented separately (Fig.

350 1B) as the $638 \mathrm{bp}$ fragment does not overlap with the Bornean shrimp tank sequence (with which it 351 groups but with no support), but otherwise optimising the alignment between other Marteilia clade 352 sequences. This tree does not differ significantly from the comparable part of Fig. $1 \mathrm{~A}$ but does 353 show that the Chinese Mytilus-derived sequence does not group with named Marteilia spp. This 354 reduced taxon-sampled tree is also interesting in that, in the absence of other genera, Eomarteilia 355 and Marteilia form a clade (see Discussion). After our analyses (Fig. 1) had been performed, 356 Marteilia octospora was described by Ruiz et al. (2016). The short 18 S fragment available for $M$. 357 octospora (within $\underline{\mathrm{KU} 641125}$ ), although not in the most variable region of the gene, is almost 358 identical to the corresponding region of M. cochillia (Fig. 1).

\subsubsection{Paramarteilia clade}

Sequences in the Paramarteilia clade were recovered from mussel-, amphipod- and crabassociated material, and comprise two distinct but closely related sequences types - one only from crustaceans to date (amphipods from the genera Echinogammarus (Short et al., 2012a,b, 2014) and Orchestia (this study)), and in incubation water from C. pagurus and Cerastoderma edule. The other 18S-type has to date only been detected in $M$. edulis incubation water. ISH probes designed

366 for the two Paramarteilia sequences (it was not possible to design different probes for each

367 sequence type) also hybridised to Paramarteilia-infected tissue in crabs $C$. pagurus (connective 368 tissue within hepatopancreas, heart, ovary, testicular follicles) and M. squinado (hepatopancreas).

369 The histology and TEM of Paramarteilia in C. pagurus and M. squinado are reported in Section 370 3.6. 
A paramyxid found in the polychaete $N$. caeca in this study (assigned to Paramyxa nephtys

374 as described in Section 3.3, and labelled as such in Fig. 1A) shares an identical sequence from

$3750.45 \mu \mathrm{m}$-filtered water from Wilcove on the Tamar estuary (not separately shown in Fig. 1A). A

376 related but clearly distinct sequence was detected in eDNA from an estuarine fish farm in Borneo.

377 A further two sequences, labelled 'Paramyxa' to tentatively assign them to this genus pending

378 ongoing morphological analysis, were detected in DNA extracted from bivalve digestive gland (DG)

379 samples from the Tamar, UK. One of these was detected at relatively high frequency in 0 . edulis

$380(62 / 222 ; 28 \%)$ and $M$. edulis $(9 / 150 ; 6 \%)$, but only in samples taken from Jupiter Point (Tamar) in

381 September 2015. The other sequence type was detected only in $1 / 150 \mathrm{M}$. edulis DG from the 2013

382 Tamar sampling.

\subsection{Paramyxid parasite of N. caeca and other polychaetes}

Histological analysis showed that $23 / 71 \mathrm{~N}$. caeca specimens sampled from the Fleet lagoon (Weymouth, UK) in May 2015 were infected with an unknown paramyxid (Fig. 2). Three of

387 these exhibited heavy infections of an ellipsoid spore-forming parasite typically restricted to the

388 intestinal tract of the worm, including the mouth, the intestinal epithelium and lumen along the full

389 length of the worm. TEM analyses of these heavily infected individuals revealed spore sacs with

390 striated projections and containing four spores, very similar to those shown for $P$. nephtys in

391 Larsson and Koie (2005). Also concordant with the description of $P$. nephtys, the developmental

392 stages of the parasite had penetrated the intestinal epithelium and replicated to replace a large

393 proportion of the host tissue. Mature stages were released from the intestinal cells into the lumen.

394 No host response to infection was noted in the epithelium or lumen. Pre-spore stages were also

395 similar to those described for $P$. nephtys. When all $71 \mathrm{~N}$. caeca samples were screened using

396 paramyxid-specific primers (see Section 2) a further 13 (i.e. total of 36 Nephtys individuals) were

397 PCR-positive. Small samples of other polychaete species were collected from the same site as the

398 N. caeca specimens. DNA from tissue of some of these was also paramyxid PCR-positive and

399 yielded the same $18 \mathrm{~S}$ sequence type in 3/5 Nereis sp. individuals, 2/14 Nemertea-like worms, 1/1 
400 Ophelia-like worms, and three unidentified polychaete individuals. We refer to this parasite as

401 Paramyxa nephtys, rather than Paramyxoides, for reasons discussed further in this report.

402

403

404

405

406

407

408

409

410

411

412

414

\subsection{Paramyxid-specific eDNA analysis}

Two lineages in Fig. 1, marked PARAM-1 and -2, have no characterised members, i.e. they have been detected only in eDNA samples. PARAM-1 comprises three identical sequences from marine sites in Florida,USA: one from a littoral filtered water sample and two from filtered water sampled within a Crassostrea virginica bed at Seahorse Key. In PARAM-2, two identical sequences (represented by GU824205 on Fig. 1) were sequenced from the same sample (and possibly the same organism) in a eukaryote-wide survey of filtered water from the Cariaco Bay, Venezuela (Edgcomb et al., 2011). The other very closely related sequence in PARAM-2 was amplified by our paramyxean-specific PCR protocol from $20 \mu \mathrm{m}$ filtered water from a bed of $C$. virginica adjacent to the Whitney Laboratory for Marine Bioscience, Florida, USA. We cannot assume that PARAM-1 or -2 belong to the genus Paramyxa as we have no morphological data for them (see Discussion).

Some of the other paramyxid clades were also represented in our eDNA screening, as shown in Fig. 3. Marteilia refringens $18 \mathrm{~S}$ rDNA was amplified from sediment and filtered water column samples from Wilcove and Cremyll in the Tamar estuary (but not Neal's Point, furthest from the sea), where it was also detected in M. edulis tissue samples (5/144 mantle; 37/287 DG) and filtered incubation water (2/17) samples. However, no sequences corresponding to $M$. cochillia, M. sydneyi, E. granula or either Marteilioides sequence type were recovered from the eDNA screens.

The $P$. orchestiae 18 s type was detected most frequently in amphipod tissue samples (whole animals) but the same sequence type was also detected in C. pagurus incubation water. A closely related sequence ( $98 \%$ similarity) was recovered from $M$. edulis incubation water (1/17 samples). In the Paramyxa clade, the only PCR amplifications from 'environmental' samples were of the $P$. nephtys $18 \mathrm{~S}$-type in $M$. edulis incubation water. 


\subsection{Geographical distribution of paramyxids}

Fig.3 suggests strong biogeographical structuring of paramyxid diversity, and that this to an extent reflects the phylogenetic clustering. Paramarteilia and Paramyxa spp are known only from Europe, Eomarteilia from Japan, and Marteilioides from the Far East (southern. Korea, Japan, eastern Australia). The Marteilia clade is apparently more widely distributed: $M$. refringens, $M$. cochillia and M. octospora mostly from Europe (other than one record from the Pacific coast of Mexico (Grijalva-Chon et al., 2015) and another from Kuwait), M. sydneyi from Australia, and many additional 'Marteilia sp.' records unconfirmed by sequencing in the literature therefore not included in Table 1 or Fig. 3. The Marteilia clade is also represented in Borneo by an environmental sequence. The environmental clades PARAM-1 and -2 were also only detected in a small number of samples - PARAM-1 in multiple samples from a single site in Florida, USA, and PARAM-2 from low latitude American continent sites (Florida and Venezuela), despite the fact that paramyxidspecific PCR was carried out on eDNA samples from Europe, the Americas, South Africa, and Borneo. None of the South African eDNA samples were paramyxid-positive.

3.6. Paramarteilia: confirmation of type species and infections in crab spp.

We present the first known 18S rDNA sequence for the Paramarteilia type species $P$. orchestiae from the type species host $O$. gammarellus, with histopathology and TEM analyses of

446 the corresponding material (confirmed by Paramarteilia-specific ISH) (Fig. 4C inset). Our light and ultrastructural observations were entirely concordant with the original description of $P$. orchestiae (Ginsburger-Vogel and Desportes, 1979). The parasite's primary cells (Fig. 4D) were between 5 $12 \mu \mathrm{m}$ in diameter and contained multivesicular bodies with spherical vacuoles and electron dense, cylindrical bacilliform haplosporomes (Fig. 4D inset). Up to nine secondary cells (sporonts, C2)

451 were observed, each individually between 3 - $7 \mu \mathrm{m}$ in diameter, and unlike the primary cells lacking 
453 present (Fig. 4D). Developmental stages of the parasite were dispersed throughout $O$.

454 gammarellus tissues and organs including the epidermal tissue (Fig. 4C,D), the connective tissue, 455 heart and ganglia of the nerve cord (Fig. 4A). Furthermore, the cells apparently 'migrate' between 456 organs and were present in the oocytes of two females (Fig. 4B), which supports the original trans457 ovarial transmission hypothesis (Ginsburger-Vogel, 1979). Although the bi- or tri-cellular stages of 458 the spore were not observed, the host species, sites of infection and morphology of the parasite unambiguously confirm this parasite as Paramarteilia orchestiae. A total of 369 O. gammarellus were prepared for histology and examined for the presence of $P$. orchestiae; infection was 461 observed in $12(3.25 \%)$ of these: one from Weymouth and 11 from Dale. A total of 222 of the 369 462 O. gamarellus individuals were screened by PCR using the Paramarteilia primers from Short et al. 463 (2012), including those analysed for histology; 24 of these were positive (10.81\%); eight from 464 Weymouth and 16 from Dale. No obvious pathology was displayed in 15 of these 24 samples. We also present the first known histopathology, ISH and TEM images of Paramarteilia 466 canceri in edible crabs and Paramarteilia in spider crabs $C$. pagurus and M. squinado, respectively 467 (Fig. 5). The morphology and infection characteristics of Paramarteilia in C. pagurus were consistent with those described for $P$. canceri in Feist et al. (2009) and the Paramarteilia infection in M. squinado was also very similar structurally. Paramarteilia canceri was observed in one of the 30 edible crabs sampled and Paramarteilia sp. was observed in two out of the 30 spider crabs

471 sampled. Developmental stages of the parasite were dispersed throughout the connective tissues 472 (Fig. 5A), hepatopancreas (Fig. 5B) and gonad (Fig. 5E, G). The parasite is shown to infect the 473 connective tissues surrounding the oocytes and the oocytes themselves (Fig. 5 E, F) as well as the 474 testicular follicles (Fig. 5G, H). The parasite in both crabs was similar to that observed in the $O$. gammarellus (see above), and that recorded from Echinogammarus marinus by Short et al.

476 (2012b), the sequence of which is shown in Fig. 1A ( 477 developmental stages present in the crab species were not observed in amphipods. At present, 478 based on morphological grounds it is not possible to propose that the same species infects these 479 hosts. Because no 18 S sequence for $P$. canceri exists (although the $P$. orchestiae 18 S sequence 480 was also detected in C. pagurus incubation water, and may correspond to Paramarteilia infecting 
481 edible crabs), and the known sequence variation with the Paramarteilia clade is very low (Fig. 1A),

482 we used the same ISH probe as for $P$. orchestiae to successfully probe for Paramarteilia in both 483 crab species (Fig. 5 insets).

\section{Discussion}

To our knowledge the phylogenetic analysis in this paper (Fig. 1A) is the first to show the relative branching positions of all paramyxid genera and species for which sequence data are available. The laterally compressed appearance of the tree in Fig. 1 may misleadingly imply low $18 \mathrm{~S}$ sequence differences. In fact all the terminal branches represent distinct lineages, with the possible exceptions of the two bivalve-derived Paramyxa sp. sequences at the top of Fig. $1 \mathrm{~A}$, and the Venezuelan and Floridean 18S-types in PARAM-2. For example, the clearly distinct M. cochillia and $M$. refringens have $99 \%$ similar 18 S sequences (1733/1742 identical nucleotide positions) and are very obviously different species based on phenotype. Many protistan species are identical, or nearly so, at the $18 \mathrm{~S}$ level (Bass et al.,2009; Boenigk et al., 2012), yet show very different host associations and sporulation characteristics. the M. chungmuensis lineage is to date exclusively associated with the clam Ruditapes philippinarum and the distinct Marteilioides sp. with Crassostrea spp. The two closely related Paramarteilia 18S types may also have different host associations (molluscs versus crustaceans), although the 'crustacean' sequence has also been detected in Cerastoderma incubation water (but may not correspond to a parasite of the cockle), and the Mytilus-associated 18S type has to date only been detected once, also in (Mytilus) incubation water. paramyxid genera are the numbers of tertiary cells (C3; which becomes the spore) produced and the number of cells constituting the spores (Feist et al., 2009). However, we show here that these are not taxonomically reliable; the unrelated Marteilioides and Marteilia both form tri-cellular 
507 spores, although from different numbers of tertiary precursor cells - two in M. sydneyi, four in $M$. 508 refringens, six in $M$. cochillia, and eight in M. octospora. The only Marteilioides sp. for which the 509 number of tertiary cells is known (M. chungmuensis) has a single tertiary precursor cell; the 510 possibility that more tertiary cells occur in other Marteilioides lineages is too great for this character 511 to be used to distinguish them from each other or from Marteilia. Furthermore, Paramarteilia, 512 grouping between Marteilia and Marteilioides (Fig. 1A), forms bi-cellular spores while Paramyxa 513 has tetra-cellular spores. Therefore there is no systematic variation in either tertiary cell number or 514 numbers of cells constituting spores with the phylogenetic branching order.

We provide the first known molecular evidence for the phylogenetic position of

516 Paramyxa/ Paramyxoides. The parasite of $N$. caeca that we analysed was ultrastructurally

517 inseparable from the description of Paramyxoides nephtys by Larsson and Koie (2005). However, 518 as the only consistent difference between $P$. nephtys and the earlier description of $P$. paradoxa 519 (Chatton, 1911) is the presence of striated radiations on the mature spore tetrads, we agree with 520 Feist et al. (2009) that Paramyxoides is a junior synonym of Paramyxa and now recognise two 521 species within the latter (original) genus: $P$. nephtys (this study) and $P$. paradoxa, which remains to 522 be sequenced, but we suggest is likely to group with the 'Paramyxa' sequences from bivalves, or 523 clades PARAM-1/-2 (Fig. 1A). A morphological description of the Paramyxa sp. sequences found 524 in bivalve tissue (Tamar) will be published separately. In the absence of morphological data we refrain from assigning PARAM-1 or -2 to

526 Paramyxa, the characterised genus to which these lineages are most closely and strongly related.

527 PARAM-1 may turn out to be P. paradoxa; however, the relationship between genotypic and 528 phenotypic distance is not straightforward, and decisions about taxonomic boundaries should be 529 made taking into account both kinds of evidence (Boenigk et al., 2012). A good illustration of this is 530 that three morphologically different Marteilia spp., M. refringens, M. cochillia and M. octospora, are 531 extremely similar at the $18 \mathrm{~S}$ level, yet Marteilia has been considered morphologically 532 indistinguishable from Marteilioides and Eomarteilia spp., all three genera being very different from 533 each other in terms of 18 S sequence similarity (Fig. 1A). Marteilia and the morphologically similar 534 but even more basally branching Eomarteilia may reflect the ancestral state for the whole order. 

separated by maximal bootstrap support from other paramyxid genera. Therefore the suppression of Marteilioides as recommended by Feist et al. (2009) and assumed by Carrasco et al. (2015) is invalid. However, Marteilioides remains a poorly sampled genus with only one described species.

539 Sequence data are required to confirm whether 'Marteilioides' branchialis groups with $M$.

540 chungmuensis or in the Paramarteilia clade, as suggested by Feist et al. (2009). Paramarteilia 541 itself is sister to Paramyxa + Marteilioides with robust support, and is therefore not directly related 542 to Marteilia.

We provide molecular (ISH) confirmation of Paramarteilia infection of edible and spider 544 crabs. The description of $P$. canceri by Feist et al. (2009) is concordant with the parasite cells 545 observed in both edible and spider crabs in this study (two bi-cellular spores). Our ISH results 546 confirm that the parasite infecting both crab species belongs to Paramarteilia, and may be the same species of Paramarteilia. However, material was not available to generate an $18 \mathrm{~S}$ sequence 548 for $P$. canceri or the Paramarteilia from M. squinado, so although the parasite of the latter was 549 morphologically indistinguishable from that in $C$. pagurus ( $P$. canceri) we cannot yet confirm it is $P$. 550 canceri until sequence data are available. Sequence data are required from both crab-infecting 551 parasites also to confirm whether their sequence is identical to $P$. orchestiae. The role of paramyxids in crab disease has received almost no attention, and will almost certainly reward future research investment. of suppression of Marteilioides, and include 'Marteilia' granula within the genus Marteilia. In the

556 Neighbour-Joining (NJ) phylogeny of Itoh et al. (2014) (Fig. 7A) 'M . granula is separated from other Marteilia spp by Marteilioides, and in an ML analysis of the same taxon sample in the same paper (Fig. 7B) and Carrasco et al. (2015; Fig. 3A), 'M . granula forms a weakly supported clade with other Marteilia spp. However, our phylogenetic analyses, which additionally include Paramyxa

560 (sister to Marteilioides) and Paramarteilia, show that including ' $M$. granula within Marteilia would 561 produce a paraphyletic Marteilia, as ' $M$ '. granula branches separately with strong support from the clade comprising $M$. refringens, $M$. cochillia and M. sydneyi in Fig. 1A. Therefore we suggest that 
563

564

565

566

567

568

569

570

571

572

573

574

575

576

577

578

579

580

581

582

583

584

585

586

587

588

589

590

'M. granula should be assigned to a new genus (Eomarteilia). Similarly, Marteilioides cannot be considered congeneric with Marteilia (see Feist et al., 2009; Carrasco et al., 2015) without incurring paraphyly of Marteilia and requiring that all other paramyxid genera be subsumed into Marteilia. It would be clearly undesirable and nonsensical to represent such a biological diversity of paramyxids as that illustrated in this study by a single genus.

It is worth noting that if an incomplete sampling of paramyxid diversity is used for phylogenetic analyses, the illusion may be given that Eomarteilia and Marteilia form a holophyletic clade (Fig. 1B); however this has very weak support compared with the more complete taxon sampling in Fig. 1A, emphasising the general desirability of comprehensive taxon sampling as a basis for the best possible phylogenetic interpretation. All of these phylogenetic relationships should be tested further by including more genes in phylogenetic analyses, when available.

Using paramyxid group-specific primers to screen e- and organismal DNA samples for 'hidden' diversity is a powerful technique, revealing novel lineages and suggesting new ecological/host associations for verification (Moreira and Lopez-Garcia, 2002; Bass et al., 2015). We detected a Paramarteilia sequence in C. pagurus sampled from the English Channel coast and incubated in sterile ASW, the histopathology and TEM of which was consistent with the description of $P$. canceri from the same site by Feist et al. (2009). We then used ISH to confirm the presence of this sequence type in both $C$. pagurus and M. squinado. This approach can be used to determine whether, for example, our detection of Paramyxa in Mytilus tissue represents actual infection or is more likely trophic passage or accumulated by filtration, and to investigate different lifecycle stages and alternative hosts (Bass et al., 2015). In fact, some aspects of our eDNA results for different paramyxid lineages may be explained by life history traits, for example sites of infection and modes of transmission. Paramarteilia orchestiae and Marteilioides spp are vertically transmitted (via host eggs); neither has been detected by eDNA methods on environmental samples. On the other hand $P$. nephtys, M. refringens, M. sydneyi, M. cochillia and Eomarteilia granula infect host digestive gland/gut tissue and are likely or known to be released from these tissues into the environment - the first two taxa in this list have been detected in environmental and well as organismal samples, and $M$. refringens has been shown to use planktonic crustacean 
591 hosts. The low current sampling levels preclude any generalisations being made from these

592 observations, but future results and experimental design should take them into account.

eDNA methods are also very useful for detecting true geographical range of lineages,

594 which as noted above, is of particular interest in paramyxean studies. However, negative eDNA

595 results are not conclusive, and the fact that we did not detect M. cochillia, M. sydneyi, E. granula or

596 either M. chungmuensis 18S types in our screens from the UK, Borneo, South Africa or Florida do

597 not signify that these taxa are not more widely distributed than implied in Fig. 3. Further probing of

598 organismal and environmental samples from more areas is required, ideally using even more

599 tightly lineage-specific primers than we used in this study to maximise detection sensitivity and

600 specificity. In general, the group-specific eDNA results from paramyxeans contrasts with that

601 earlier obtained for Haplosporida (Hartikainen et al., 2014a), which revealed higher levels of

602 diversity and higher detection frequencies from environmental samples. The paramyxid results are

603 perhaps more akin to those for mikrocytids (Hartikainen et al., 2014b), which were more limited in

604 environmental samples and detection was often more strongly associated with potential hosts or

605 particular environmental compartments. It may be that paramyxids and mikrocytids are more tightly

606 host-associated than haplosporidans and/or they less frequently infect small planktonic animals

607 (and are consequently less likely to be captured by sampling of planktonic habitats) either as

608 primary or alternative hosts.

A further complexity in the use of eDNA and host screening methods for the detection of novel and existing paramyxid diversity is a lack of understanding surrounding the role played by

611 environmental conditions in the prevalence and pathogenicity of most lineages. Microscopy-based

612 studies suggest the minimum water temperature of $18-20^{\circ} \mathrm{C}$ necessary for gonad maturation in $C$.

613 gigas is similar to that required for development of M. chungmuensis within host oocytes (Kang et

614 al., 2000; Ngo et al., 2013), and follow-up studies utilising both microscopy and PCR seem to

615 confirm this (Tun et al., 2008). Temperature has also been shown to be a key parameter in the life

616 cycle of $M$. refringens (Berthe et al., 1998) and M. sydneyi (Rubio et al., 2013). Therefore it is

617 essential to account for environmental conditions and seasonality in eDNA (and other) sampling

618 efforts. The 'window of infection' (i.e. the timespan over which infection is observable in the bivalve 
619 host) also varies between taxa, and within the same taxa across several years. Onset of the

620 infection window of M. sydneyi in S. glomerata often follows a rapid decrease in water salinity, and

621 can last between 8 and 18 weeks, though the exact environmental conditions determining this

622 window remain unknown (Rubio et al., 2013).

Our attempt to collate distribution and host association data from all recorded paramyxid

624 species to date has, in tandem with the phylogenetic analysis, suggested a strong biogeographical

625 structuring of paramyxid lineages. The closely related $M$. refringens, $M$. cochillia and $M$. octospora

626 have only been recorded in Europe (the latter two only from Spain to date), whereas the more

627 distantly related M. sydneyi has been reported only from Australia (both east and west coasts

628 when non-sequenced records are considered), suggesting that geographically distant lineages are

629 likely to be more distantly related. Further highly distinct lineages were sampled in Malaysian

630 Borneo (shrimp larvae hatchery tank), South Korea (Marteilia sp. MC), and the Yellow Sea and

631 East Sea coasts of China (paramyxid ex. Mytlius), where both the native mussel Perna viridis and

632 the non-native Mytilus edulis were infected (Fig. 1B). The infection of M. edulis at these sites

633 suggests that other populations of this mussel are potentially threatened by 'new' parasite lineages

634 in other regions of the world, at least where ecological conditions permit. Marteilioides reports

635 confirmed by sequence data are restricted to South Korea and Japan, with non-sequenced records

636 from Australia. Paramyxa (including Paramyxoides) has only been reported from Europe

637 (Denmark, UK, France), and Paramarteilia only from the UK and (the original unsequenced type

638 material) from northern France.

Patchy and low sampling effort explains at least some of these geographical observations.

640 Paramyxa and Paramarteilia have only been studied at a small number of sites by very few 641 researchers. An informed and more widely distributed sampling effort (including eDNA methods;

642 Bass et al., 2015 and this study), is necessary and very likely to prove broader distributions for 643 many paramyxid lineages. However, lineages that have been more intensively studied, for 644 example $M$. refringens and $M$. sydneyi, are more likely to have been found without and within 645 Europe, respectively, if they were present. Even so, there are many discoveries to be made, as 646 demonstrated by the very recent findings of $M$. refringens in the oysters $C$. gigas and Crassostrea 
647 corteziensis in Mexico (Grijalva-Chon et al., 2015), and M. octospora in Spain (Ruiz et al., 2016).

648 Limited 18 S data show M. octospora to be very closely related to $M$. cochillia, and while $18 \mathrm{~S}$ data

649 are not available for the Mexican $M$. refringens, their IGS rDNA sequences are only $0.3-2.2 \%$

650 dissimilar to M. refringens from a Spanish clam, Chamelea gallina (AM292652); with such similar

651 sequences in the highly variable IGS region their $18 \mathrm{~S}$ sequences are likely to be extremely similar

652 or identical to the M. refringens sequences represented in Fig. 1.

There exist many potential paramyxid lineages for which inadequate microscopic or molecular data are available to establish their taxonomic affinity. For example, a Marteilia sp. has been observed at low prevalence (2\% of 140 sampled) infecting the digestive gland of cultured rock oysters Saccostrea forskali in Chonburi Province, Thailand (Taveekijakarn et al., 2008). Similarly, unidentified Marteilioides sp. and Marteilia sp. have been observed (in the oocytes and digestive gland, respectively) of the Manila clam, R. philippinarum, in Japan (Itoh et al., 2005). These parasites are present at very low prevalence and have yet to be linked to any significant pathogenicity in their hosts. A further undescribed potential Marteilia sp. was also observed

661 infecting the digestive diverticulum of the calico scallop, Argopecten gibbus, off Cape Canaveral, 662 Florida, USA in 1988-1989 (Moyer et al., 1993). This parasite resulted in the rapid decimation of 663 the scallop population, but further attempts to collect material for ultrastructural analysis were unsuccessful. Although the taxonomic affiliations of this parasite remain unknown, a recent survey of calico scallop abundance in this area and the Gulf of Mexico shelf suggests the parasite is still 666 prevalent at both sites, with late stage infections common (Geiger et al., 2015). Further 667 investigation is needed to ascertain the identity of the parasite and its effect upon the commercial 668 viability of the scallop populations in these areas. than is true for many protists (Bass and Boenigk, 2011), the diversity and distribution of the order

671 as a whole is greater than shown in Fig. 1 and Table 1. A more complete understanding of the 672 distributions of these pathogens is increasingly important as new lineages (often with economically 673 significant effects) are being discovered, and known paramyxids are being found in new hosts

674 and/or locations (e.g. M. chungmuensis, Itoh et al., 2004; P. canceri, Feist et al., 2009; M. 
675

676

677

678

679

680

681

684

685

686

696

698

699

700

refringens, Arzul et al., 2014; M. sydneyi, Adlard and Nolan, 2015). Human-mediated transport of these pathogens around the world could introduce them into areas in which they could become active if suitable environmental and/or lifecycle conditions arise. This also applies to other understudied parasites with similar apparently restricted geographical ranges, even though more intensive sampling facilitated by modern molecular screening methods also shows these to be more widespread and diverse than previously thought (e.g. haplosporidians and mikrocytids; Harikainen et al., 2014a,b).

Our new data and literature survey indicate that paramyxid lineages are being discovered on a regular basis, and perhaps with increasing frequency as knowledge of the group and methods to detect them improve. Initiatives such as the new Paramyxean Working Group (http://paramyxeanworkingroup.org/) demonstrate that the international community has become more aware and interested in paramyxid research and there is a requirement and appetite for developing this neglected field. However, it remains difficult to estimate the potential emergence and impact of paramyxids on animal hosts of human concern, and their even more hidden roles as parasites in diverse and interacting marine ecosystems because so little is known of their true diversity and distribution. In this study we provide some molecular tools for targeted detection of the full range of known paramyxids in environmental and organismal matrices. Our phylogenetic analysis provides an evolutionary context for understanding how the group has evolved in terms of morphology, distribution and lifecycle. The recent demonstrations that paramyxids occur in a wider range of hosts and environments than previously thought encourage us to study them and their pathogenesis in an ecological context, in addition to their individual effects on key host taxa. There is a need for greater genomic sampling of paramyxids, both to increase the power of phylogenetic (multi-gene) analyses of the group, and to better understand the nature of host-parasite interactions.

\section{Acknowledgements}


GW was supported by a Natural Environment Research Council GW4+ Doctoral Training

702 Programme PhD studentship held at Exeter University, UK, The Natural History Museum (NHM),

703 UK and Centre for Environment, Fisheries and Aquaculture Science (Cefas), UK; DB, GDS and KB

704 by Department for Environment, Food and Rural Affairs (Defra), UK contract FC1212 and SWF by

705 Defra contract FB002 to Cefas; DB also by Natural Environment Research Council, UK grant

$706 \mathrm{NE} / \mathrm{H} 000887 / 1$. SW was supported by Grant-in-Aid funding from the Department of Life Sciences

707 at the NHM. MB was supported by a Defra student placement at Cefas. CB was supported by the

708 'Investissements d'Avenir' programme OCEANOMICS (ANR-11-BTBR-0008) awarded by the

709 French Government via Agence Nationale de la Recherche. We thank Stuart Ross and Matthew

710 Green for invaluable assistance with sampling, and Julian Ransangan for hosting and assistance

711 in Borneo, Cecile Reed (South Africa), Mark Martindale and Maria Romerlo (Florida, USA), and

712 Rachel Foster at NHM for assistance with sample processing.

713

714 
715

716

717

718

719

720

721

722

723

724

725

726

727

728

729

730

731

732

733

734

735

736

737

738

739

740

741

742

743

\section{References}

Adlard, R.D., Nolan, M.J., 2015. Elucidating the life cycle of Marteilia sydneyi, the aetiological agent of QX disease in the Sydney rock oyster (Saccostrea glomerata). Int. J. Parasitol. 45, 419-426.

Anderson, T.J., Lester, R.J.G., 1992. Sporulation of Marteilioides branchialis N. sp. (Paramyxea) in the Sydney Rock Oyster, Saccostrea commercialis: An Electron Microscope Study. J. Protozool., 39, 502-508.

Arzul, I., Chollet, B., Boyer, S., Bonnet, D., Gaillard, J., Baldi, Y., Robert, M., Joly, J-P., Garcia, C., Bouchoucha, M., 2014. Contribution to the understanding of the cycle of the protozoan parasite Marteilia refringens. Parasitology 141, 227-40.

Audemard, C., Le Roux, F., Barnaud, A., Collins, C., Sautour, B., Sauriau, P-G., de Montaudouin, X., Coustau, C., Combes, C., Berthe, F., 2001. Needle in a haystack: involvement of the copepod Paracartia grani in the life-cycle of the oyster pathogen Marteilia refringens. Parasitology 124, 315-323.

Bass, D., Chao, E.E.Y., Nikolaev, S., Yabuki, A., Ishida, K-i., Berney, C., Pakzad, U., Wylezich, C., Cavalier-Smith, T., 2009. Phylogeny of novel naked filose and reticulose Cercozoa: Granofilosea cl. n. and Proteomyxidea revised. Protist 160, 75-109.

Bass, D., Boenigk, J. 2010. Everything is Everywhere: a $21^{\text {st }}$ Century De-/Reconstruction. In: Fontaneto, D. (Ed.), Biogeography of Microscopic Organisms: Is Everything Everywhere? The Systematics Association, Cambridge University Press, UK, pp. 88-110.

Bass, D., Stentiford, G.D., Littlewood, D.T.J., Hartikainen, H., 2015. Diverse applications of environmental DNA methods in parasitology. Trends Parasitol. 31, 499-513. 
745 Berthe, F.C.J., Pernas, M., Zerabib, M., Haffner, P., Thébault, A., Figueras, A.J., 1998.

746 Experimental transmission of Marteilia refringens with special consideration of its life cycle.

747 Dis. Aquat. Org. 34, 135-144.

748

749 Berthe, F.C.J., Le Roux, F., Peyretaillade, E., Peyret, P., Rodriguez, D., Gouy, M., Vivarès, C.P., 750 2000. Phylogenetic analysis of the Small Subunit Ribosomal RNA of Marteilia refringens Validates the Existance of Phylum Paramyxea (Desportes and Perkins, 1990). J. Eukaryot.

Berthe, F.C.J., Le Roux, F., Adlard, R.D., Figueras, A., 2004. Marteiliosis in molluscs: A review. Aquat. Living Resour. 17, 433-448.

756

757

758

759

760

761

762

763

764

765

766

767

768

769

770

771

772 Microbiol. 47, 288-293.

Bhaby, S., Belhsen, O.K., Errhif, A., Tojo, N., 2013. Seasonal dynamics of parasites on Mediterranean mussels Mytilus galloprovincialis and ecological determinants of the infections in Southern Alboran Area, Morocco. Int. J. Parasitol. Res. 5, 116-121.

Bignell, J.P., Stentiford, G.D., Taylor, N.G.H., Lyons, B.P., 2011. Histopathology of mussels (Mytilus sp.) from the Tamar estuary, UK. Mar. Environ. Res. 72, 25-32.

Boenigk, J., Ereshefsky, M., Hoef-Emden, K., Mallet, J., Bass, D., 2012. Concepts in protistology: species definitions and boundaries. Eur. J. Protistol. 48, 96-102.

Boyer, S., Chollet, B., Bonnet, D., Arzul, I., 2013. New evidence for the involvement of Paracartia grani (Copepoda, Calanoida) in the life cycle of Marteilia refringens (Paramyxea). Int. J. Parasitol. 43, 1089-1099.

Carella, F., Aceto, S., Marrone, R., Maiolino, P., De Vico, G., 2010. Marteilia refringens infection in cultured and natural beds of mussels (Mytilus galloprovincialis) along the Campanian coast 
774

775 Carrasco, N., Lópes-Flores, I., Alcaraz, M., Furones, M.D., Berthe, F.C.J., Arzul, A., 2007a. First

776

777

778

779

780

781

782

783

784

785

786

787

788

789

790

791

792

793

794

795

796

797

798

799

800

801

record of a Marteilia parasite (Paramyxea) in zooplankton populations from a natural estuarine environment. Aquaculture 269, 63-70.

Carrasco, N., Lópes-Flores, I., Alcaraz, M., Furones, M.D., Berthe, F.C.J., Arzul, I., 2007b. Dynamics of the parasite Marteilia refringens (Paramyxea) in Mytilus galloprovincialis and zooplankton populations in Alfacs Bay (Catalonia, Spain). Parasitology 134, 1541-1550.

Carrasco, N., Arzul, I., Berthe, F.C.J., Furones, M.D., 2008. In situ hybridization detection of initial infective stages of Marteilia refringens (Paramyxea) in its host Mytilus galloprovincialis. J. Fish. Dis. 31, 153-157.

Carrasco N. P., Andree K.B., Lacuesta B., Roque A., Rodgers C. and Furones M.D., 2012. Molecular characterization of the Marteilia parasite infecting the common edible cockle Cerastoderma edule in the Spanish Mediterranean coast: A new Marteilia species affecting bivalves in Europe? Aquaculture 324-325, 20-26.

Carrasco N., Hine,P.M., Durfort M., Andree K.B., Malchus N., Lacuesta B., González M., Roque A., Rodgers C., Furones M.D., 2013. Marteilia cochillia sp. nov., a new Marteilia species affecting the edible cockle Cerastoderma edule in European waters. Aquaculture 412-413, 223-230.

Carrasco, N., Green, T., Itoh, N., 2015. Marteilia spp. parasites in bivalves: A revision of recent studies. J. Invertebr. Pathol. 131, 43-57.

Cavalier-Smith T., Chao E.E.Y., 2003a, Phylogeny of Choanozoa, Apusozoa, and other protozoa and early eukaryote megaevolution. J. Mol. Evol. 56, 540-563. 
802

803 Cavalier-Smith, T., Chao E.E.Y., 2003b, Phylogeny and classification of phylum Cercozoa

$804 \quad$ (Protozoa). Protist 154, 341-358.

805

806

807

Chatton, E., 1911. Sur une Cnidosporidie sans cnidoblaste (Paramyxa paradoxa n. g., n. sp.). C.

808

809

810

Comps, M., Grizel, H., Tige, G., Duthoit, J-L., 1975. Parasites nouveaux de la glande digestive des 811 Mollusques marins Mytilus edulis L. et Cardium edule L. C. R. Acad. Sc. Paris 281, 179.

Comps, M., 1976. Marteilia lengehi n. sp. parasite de l'huitre Crassostrea cucullata Born. Rev.

Comps, M., Grizel, H., Papayanni, Y., 1982. Infection parasitaire causée par Marteilia maurini sp.

Desportes, 1., Ginsburger-Vogel, T., 1977. Ultrastructure du centriole de Marteilia sp., protiste parasite d'Orchestia gammarellus (Pallus) (Crustacea, Amphipod). Protistologica 13: 607610.

Desportes, I., Lom, J., 1981. Affinitiés de Paramyxa paradoxa Chatton 1911, parasite de Poecilochaetus serpens (Annélide Polychaete) avec les Marteiliidae Sprague, parasites 632. 
831 Desportes I., Perkins F.O., 1990, Phylum Paramyxea. In: L. Margulis, J.O. Corliss, M. Melkonian, D.J. Chapman (Eds.), Handbook of Protoctista. Jones and Bartlett Publishing, Boston, USA, pp. 30-35.

Edgcomb,V., Orsi,W., Bunge,J., Jeon,S., Christen,R., Leslin,C., Holder,M., Taylor,G.T., Suarez,P., Varela,R. and Epstein,S., 2011. Protistan microbial observatory in the Cariaco Basin, Caribbean. I. Pyrosequencing vs Sanger insights into species richness. ISME J 5(8), 13441356.

Elgharsalli, R., Aloui-Bejaoui, N., Salah, H., Chollet, B., Joly, J-P., Robert, M., Couraleau, Y., Arzul,

Feist S.W., Hine M. S., Bateman K.S., Stentiford G.D. and Longshaw M., 2009. Paramarteilia cancerisp. n. (Cercozoa) in the European edible crab (Cancer pagurus) with a proposal for I., 2013. Characterisation of the protozoan parasite Marteilia refringens infecting the dwarf oyster Ostrea stentina in Tunisia. J. Inv. Pathol. 112, 175-183.

Ginsburger-Vogel, T., Desportes, I., Zerbib, C., 1976. Présence chez l'amphipode Orchestia gammarellus (Pallas). d'un protiste parasite, ses affinités avec Marteilia refringens agent de the revision of the order Paramyxida Chatton, 1911. Folia Parasit. 56, 73-85.

Geiger, S.P., Arnold, W.S., Stephenson, S., Fischer, K., 2015. Calico scallop Argopecten gibbus abundance on the Cape Canaveral bed and on Florida's Gulf of Mexico shelf. Mar. Coast. Fish. 7, 497-513. l'épizootie de l'huître plate. C.R. Acad. Sci. Paris 283, 939-942. 
860

861

862

863

864

865

866

867

868

869

870

871

872

873

874

875

876

877

878

879

880

881

882

883

884

885

886

887

Ginsburger-Vogel, T., 1991. Intersexuality in Orchestia mediterranea Costa, 1853, and Orchestia aestuarensis Wildish, 1987 (Amphipoda): A consequence of hybridization or parasitic infestation? J. Crust. Biol. 11, 530-539.

Gombac, M., Kušar, D., Ocepek, M., Pogačnik, M., Arzul, I., Couraleau, Y., Jenčič, V., 2014. Marteiliosis in mussels: a rare disease? J. Fish Dis. 37, 805-814.

Grijalva-Chon, J.M., Castro-Longoria, R., Enriquez-Espinosa, T.L., Maeda-Martinez, A.N., Mendoza-Cano, F., 2015. Molecular evidence of the protozoan parasite Marteilia refringens in Crassostrea gigas and Crassostrea corteziensis from the Gulf of California. Lat. Am. J. Aquat. Res. 43, 776-780.

Grizel, H., Comps, M., Bonami, J.R., Cousserans, F., Duthoit, J.L., Le Pennec, M.A., 1974. Recherche sur l'agent de le maladie de la glande digestive de Ostrea edulis Linné. Science et Peche. Bull. Inst. Pêches Marit. 240, 7-30.

Hartikainen, H., Ashford, O.S., Berney, C., Okamura, B., Feist, S.W., Baker-Austin, C., Stentiford G.D., Bass, D., 2014a. Lineage-specific molecular probing reveals novel diversity and ecological partitioning of haplosporidians. ISME J 8, 177-186.

Hartikainen, H., Stentiford, G.D., Bateman, K.S., Berney, C., Feist, S.W., Longshaw, M., Okamura, B., Stone, D., Ward, G., Wood, C., Bass, D., 2014b. Mikrocytids are a broadly distributed and divergent radiation of parasites in aquatic invertebrates. Curr. Biol. 24, 807-812.

Itoh, N., Oda, T., Yoshinaga, T., Ogawa, K., 2003. Isolation and 18S ribosomal DNA gene sequences of Marteilioides chungmuensis (Paramyxea), an ovarian parasite of the Pacific oyster Crassostrea gigas. Dis. Aquat. Org. 54, 163-169. 
888 Itoh, N., Komiyama, H., Ueki, N., Ogawa, K., 2004. Early developmental stages of a protozoan parasite, Marteilioides chungmuensis (Paramyxea), the causative agent of the ovary

890 enlargement disease in the Pacific oyster, Crassostrea gigas. Int. J. Parasitol. 34, 11291135.

892

893 Itoh, N., Momoyama, K., Ogawa, K., 2005. First report of three protozoan parasites (a haplosporidian, Marteilia sp. and Marteilioides sp.) from the Manila clam, Venerupis (=

896

Itoh N., Yamamoto T.,Kang H.S., Choi K.S., Green T.J.,Carrasco,N., Awaji M. and Chow,S., 2014.

898

899

900

901

902

903

904

905

906

907

908

909

910

911

912

913

914

915

916 Ruditapes) philippinarum in Japan. J. Inv. Path. 88, 201-206. A novel paramyxean parasite, Marteilia granula sp. nov.(Cercozoa),from the digestive gland of Manila clam, Ruditapes philippinarum, in Japan. J. Fish Pathol. 49, 181-193.

Kang, C-K., Park, M-S., Lee, P-L., Choi, W-J., Lee, W-C., 2000. Seasonal variations in condition, reproductive activity, and biochemical composition of the Pacific oyster Crassostrea gigas (Thunberg), in suspended culture in two coastal bays of Korea. J. Shellfish Res. 19, 771778.

Katoh, K., Standley, D.M., 2013. MAFFT multiple sequence alignment software version 7: improvements in performance and usability. Mol. Biol. Evol. 30, 772-780.

Larsson, J.I.R., Køie, M., 2005. Ultrastructural study and description of Paramyxoides nephtys gen. n., sp. n. a parasite of Nephtys caeca (Fabricius, 1780)(Polychaeta:Nephtydae). Acta Protozool. 44, 175-187.

Lee, A.K., Cho, B-Y., Lee, S-J., Kang, J-Y., Jeong, H.D., Huh, S.H., 2001. Histopathological lesions of Manila clam, Tapes philippinarum, from Hadong and Namhae coastal areas of Korea. Aquaculture 201, 199-209. 
917

918

919

920

921

922

923

924

925

926

927

928

929

930

931

932

933

934

935

936

937

938

939

940

941

942

943

944

945

Lópes-Flores, I., Robles, F., Valencia, J.M., Grau, A., Villalba, A., de la Herrán, R., Garrido-Ramos, M.A., Ruiz-Rejón, C., Ruiz-Rejón, M., Navas, J.I., 2008a. Detection of Marteilia refringens using nested PCR and in situ hybridisation in Chamelea gallina from the Balearic Islands (Spain). Dis. Aquat. Org. 82, 79-87.

Lópes-Flores, I., Garrido-Ramos, M.A., de le Herran, R., Ruiz-Rejón, C, Ruiz-Rejón, M., Navas, J.I., 2008b. Identification of Marteilia refringens infecting the razor clam Solen marginatus by PCR and in situ hybridisation. Mol. Cell. Probes 22, 151-155.

Moyer, M.A., Blake, N.J., Arnold, W.S., 1993. An Ascetosporan disease causing mass mortality in the Atlantic calico scallop Argopecten gibbus (Linnaeus, 1758)., J. Shellfish Res. 12, 305310.

Neuhauser S., Kirchmair M., Bulman S., Bass D., 2014 Cross-kingdom host shifts of phytomyxid parasites. BMC Evol. Biol. 14, 33.

Ngo, T.T.T., Berthe, F.C.J., Choi, K-S., 2003. Prevalence and infection intensity of the ovarian parasite Marteilioides chungmuensis during an annual reproductive cycle of the oyster Crassostrea gigas. Dis. Aquat. Org. 56, 259-267.

Nishiguchi, M.K., Doukakis, P., Egan, M., Kizirian, D., Phillips, A., Predini, L., Rosenbaum, H.C., Torres, E., Wyner, Y., DeSalle, R., Giribet, G., 2002. DNA Isolation Procecures. In: DeSalle, R., Giribet, G., Wheeler, W.C. (Eds), Techniques in Molecular Systematics and Evolution. Birkhäuser Verlag Basel, Switzerland, pp. 249-187.

Pascual, S., Villalba, A., Abollo, E., Garci, M., González, A.F., Nombela, M., Posada, D., Guerra, A., 2010. The mussel Xenostrobus secures: a well-established alien invader in the Ria de Vido (Spain, NE Atlantic). Biol. Invasions 12, 2091-2103. 
946

947

948

949

950

951

952

953

954

955

956

957

958

959

960

961

962

963

964

965

966

967

968

969

970

971

972

973

974

Perkins, F.O., 1976. Ultrastructure of sporulation in the European flat oyster pathogen Marteilia refringens - taxonomic implications. J Protozool. 27, 64-74.

Perkins, F.O. \& Wolf, P.H., 1976. Fine structure of Marteilia sydneyi n. sp. - haplosporidian pathogen of Australian oysters. J. Parasitol. 62, 528-538.

Perkins, F.O., 1979. Cell structure of shellfish pathogens and hyperparasites in the genera Minchinia, Urosporidium, Haplosporidium, and Marteilia - taxonomic implications. In: Perkins F.O., (Ed.), Haplosporidian and Haplosporidian-like Diseases of Shellfish. Mar. Fish. Rev. 41, 25-37.

Poulin, R., Randhawa, H.S., 2015. Evolution of parasitism along convergent lines: from ecology to genomics. Parasitology 142(Suppl 1), S6-S15.

Ronquist F., Teslenko M., van der Mark P., Ayres D.L., Darling A., Höhna S., Larget B., Liu L., Suchard M.A., Huelsenbeck J.P., 2012. MrBayes 3.2: efficient Bayesian phylogenetic inference and model choice across a large model space. Syst. Biol. 61, 539-42.

Rubio, A., Frances, J., Coad, P., Stubbs, J., Guise, K., 2013. The onset and termination of the QX Disease window of infection in Sydney rock oyster (Saccostrea glomerata) cultivated in the Hawkesbury River, NSW, Australia. J. Shellfish Res. 32, 483-496.

Ruiz, M., López, C., Lee, R-S., Rodríguez, R., Darriba, S., 2016. A novel paramyxean parasite, Marteilia octospora n. sp. (Cercozoa) infecting the grooved razor shell clam Solen marginatus from Galicia (NW Spain). J. Inv. Path. 135, 34-42.

Short, S., Guler, Y., Yang, G., Kille, P., Ford, A.T., 2012a. Paramyxean-microsporidian co-infection in amphipods: is the consensus that Microsporidia can feminize their hosts presumptive? Int. J. Parasitol. 42, 683-691. 
976 Short S., Yang G., Kille P., Ford A.T., 2012b. A widespread and distinctive form of amphipod intersexuality not induced by known feminising parasites. Sex. Dev. 6, 320-324.

978

979

980

981

982

983

984 985

986

987

988

989

990

991

992

993

994

995

996

997

998

999

1000

1001

1002

Short, S., Yang, G., Guler, Y., Green, T., Etxabe, A., Kille, P., Ford, A.T., 2014. Crustacean intersexuality is feminization without demasculinization: implications for environmental toxicology. Environ. Sci. Technol. 48, 13520-13529.

Stamatakis, A., 2014. RAxML Version 8: A tool for Phylogenetic Analysis and Post-Analysis of Large Phylogenies. Bioinformatics 30, 1312-1313.

Stentiford, G.D., Feist, S.W., Stone, D.M., Peeler, E.L., Bass, D., 2014. Policy, phylogeny and the parasite. Trends Parasitol. 30, 274-281.

Taveekijakarn, P., Somsiri, T., Puttinaowarat, S., Tundavanitj, S., Chinabut, S., Nash, G., 2008. Parasitic Fauna of Rock Oyster (Saccostrea forskali) cultured in Thailand. In: BondadReantaso, M.G., Mohan, C.V., Crumlish, M. and Subasinghe, R.P. (Eds). Diseases in Asian Aquaculture VI. Fish Health Section, Asian Fisheries Society, Manila, Philippines. pp.335-342.

Tun, K.L., Shimizu, Y., Yamanoi, H., Yoshinaga, T., Ogawa, K., 2008. Seasonality in the infection and invasion of Marteilioides chungmuensis in the Pacific oyster Crassostrea gigas. Dis. Aquat. Org. 80, 157-165.

Villalba, A., Mourelle, S.G., López, M.G., Carballal, M.J., Azevedo, C., 1993. Marteiliasis affecting cultured mussels Mytilus galloprovincialis of Galicia (NW Spain). I. Etiology, phases of the infection, and temporal and spatial variability in prevalence. Dis. Aquat. Org. 16, 61-72. 
1003 Villalba, A., Iglesias, D., Ramilo, A., Darriba, S., Parada, J.M., No, E., Abollo, E., Molares, J.,

1004 Carballal, M.J., 2014. Cockle Cerastoderma edule fishery collapse in the Ría de Arousa

1005 (Galicia, NW Spain) associated with the protistan parasite Marteilia cochillia. Dis. Aquat.

1006 Org. 109, 55-80.

1007

1008 Wang, Z., Lu, X., Liang, Y., Zheng, Z., 2012. A Marteilia-like parasite in blue mussels Mytilus edulis

1009 in China. J. Aquat. Anim. Health 24, 161-164.

1010

1011 Yanin, L., Kang, H-S., Hong, H-K., Jeung, H-D., Kim, B-K., Le, T.C., Kim, Y-O., Choi, K-S., 2013.

1012 Mulecular and histological identification of Marteilioides infection in Suminoe Oyster

1013 Crassostrea ariakensis, Manila Clam Ruditapes philippinarum and Pacific Oyster

1014 Crassostrea gigas on the south coast of Korea. J. Invertebr. Path. 114, 277-284.

1015

1016 Zrnčić, S., Le Roux, F., Oraić, D., Šoštarić, B., Berthe, F.C.J., 2001. First record of Marteilia sp. in

1017 mussels Mytilus galloprovincialis in Croatia. Dis. Aquat. Organ. 44, 143-148.

1018

1019 
1020

1021

1022

1023

1024

1025

1026

1027

1028

1029

1030

1031

1032

1033

1034

1035

1036

1037

1038

1039

1040

1041

1042

1043

1044

1045

1046

1047

1048

\section{Figure and Table legends}

Fig. 1. 18S rDNA phylogenies of paramyxids and relevant GenBank accession numbers. (A) Phylogeny of paramyxids generated using Bayesian Inference. Values on nodes indicate Bayesian Posterior Probabilities (BPP); filled circles on nodes indicate maximal support (BPP $=1.0$ ). Coloured/shaded squares indicate lineages detected in environmental samples, and circles those detected in host-associated (tissue or incubation) samples. Triangles indicate lineages for which only environmental sequences exist. Values in shapes indicate prevalence (number of positive samples/number of samples screened). Where no value is present, the lineage was not detected in this study. (B) More complete phylogeny of Marteilia and Eomarteilia with Paramarteilia orchestiae as an outgroup, generated using Bayesian Inference, showing Maximum Likelihood bootstrap and BPP values.

Fig. 2. Transmission Electron Micrographs (TEMs) and supporting light micrographs (H\&E), in-situ hybridisation (ISH) of developing and fully matured morphological Paramyxa nephtys cells. (A) Developing $P$. nephtys cells detailing the third to sixth nuclei (N3 - N6) of a developing $P$. nephtys spore. TEM. Scale bar $=2 \mu \mathrm{m}$. (B) Longitudinal view of two mature $P$. nephtys spores, encased within spore sacs possessing striated projections (SP). TEM. Scale bar $=2 \mu \mathrm{m}$. (C) Top-down view of $P$. nephtys spore sac terminal striated projection (SP) showing the projections form a single structure. TEM. Scale bar $=2 \mu \mathrm{m}$. (D) Longitudinal view of two mature $P$. nephtys spores. H\&E Stain. Scale bar $=25 \mu \mathrm{m}$. (E) Longitudinal view of two mature $P$. nephtys spores. ISH. Scale bar $=$ $25 \mu \mathrm{m}$. (F) Transverse section of four coupled $P$. nephtys spores demonstrating the four tetracellular spore arrangement (C1 - C4). TEM. Scale bar $=2 \mu \mathrm{m} .(\mathrm{G})$ Transverse section of $P$. nephtys spores. H\&E Stain. Scale bar $=25 \mu \mathrm{m}$. (H) Transverse section of $P$. nephtys spores. Inset ISH. Scale bar $=25 \mu \mathrm{m}$.

Fig. 3. World map showing distribution of paramyxid clades. Coloured/shaded squares indicate detection of a lineage in environmental samples, and circles those detected in confirmed hosts or 
1049 host-associated samples. Triangles indicate lineages for which only environmental sequences

1050 exist. Shapes labelled with asterisks represent lineages detected in this study. The inset shows the

1051 distribution of paramyxids within Europe.

1052

1053 Fig. 4. Light and electron micrographs depicting Paramarteilia orchestiae cells in Orchestia

1054 gammarellus tissue. (A) Multiple groups of $P$. orchestiae cells (arrows) within connective tissues

1055 surrounding ganglion of nerve cord. H\&E. Scale bar $=10 \mu \mathrm{m}$. (B) Intracellular $P$. orchestiae in

1056 oocytes (black arrow) and the connective tissue capsule surrounding the oocytes (white arrow).

1057 H\&E. Scale bar $=10 \mu \mathrm{m}$. (C). Cluster of $P$. orchestiae cells at different stages of development $\left(^{*}\right)$

1058 within the connective tissue of the leg. H\&E. Scale bar $=10 \mu \mathrm{m}$. Inset: in situ hybridisation (ISH)

1059 labelling of the $P$. orchestiae cells within the connective tissue of the leg (arrow). Scale bar $=10$

$1060 \mu \mathrm{m}$. (D) Individual P. orchestiae cell showing the cell-within-cell arrangement of the parasite.

1061 Primary cell $\left({ }^{*}\right)$ contains secondary cells (C2). H\&E. Scale bar $=10 \mu \mathrm{m}$. Inset: Transmission

1062 Electron Micrograph of $P$. orchestiae cell demonstrating primary cell $(\mathrm{C} 1)$ and a secondary cell

1063 (C2) containing nucleus (N2). Scale bar $=2 \mu \mathrm{m}$.

1064

1065 Fig. 5. Paramarteilia canceri infecting edible crab (Cancer pagurus) tissues and Paramarteilia sp.

1066 infecting spider crab (Maja squinado) tissues. (A) Paramarteilia canceri infecting the connective

1067 tissue cells (arrows) within the haemal spaces of the hepatopancreas. Edible crab. H\&E. Scale bar

$1068=25 \mu \mathrm{m}$. Inset: in situ hybridisation (ISH) labelling the $P$. canceri cells within the connective tissues

1069 in the hepatopancreas. Edible crab. Scale bar $=25 \mu \mathrm{m}$. (B) Paramarteilia sp. within the

1070 hepatopancreatic tubule epithelial cells (arrows). Spider crab. H\&E. Scale bar $=25 \mu \mathrm{m}$. Inset: ISH

1071 labelling of Paramarteilia sp. (arrow) at the base of the hepatopancreatic tubule epithelium $\left(^{*}\right)$.

1072 Spider crab. Scale bar $=10 \mu \mathrm{m}$. (C) Transmission electron micrograph (TEM) of $P$. canceri

1073 infecting the connective tissue cells within the heart detailing the cell-within-cell arrangement of the

1074 parasite. Primary cell (C1) contains secondary (C2) and tertiary (C3) cells, electron dense

1075 haplosporosomes (black arrows) and multivesicular bodies (white arrows). Edible crab. Scale bar $=$

$10761 \mu \mathrm{m}$. (D) Paramarteilia canceri infecting the connective tissue cells (arrow) within the heart.

1077 Edible crab. H\&E. Scale bar $=10 \mu \mathrm{m}$. Inset: ISH labelling of $P$. canceri infecting the connective 
1078 tissue cells (arrow) within the heart. Edible crab. Scale bar $=10 \mu \mathrm{m}$. (E) Intracellular P. canceri

1079 infecting the ovary (black arrow) and the connective tissues of the ovary (white arrow). H\&E. Edible

1080 crab. Scale bar $=10 \mu \mathrm{m}$. Inset: ISH labelling of $P$. canceri infecting the oocytes themselves (black

1081 arrow) and the connective tissues of the ovary (white arrow). Edible crab. Scale bar $=10 \mu \mathrm{m}$. (F)

1082 TEM of $P$. canceri within a vitellogenic oocyte. The oocyte is almost completely filled with yolk

1083 globules (white arrow) the multicellular P. canceri parasites (black arrow) are clearly visible within

1084 the oocyte. Edible crab. Scale bar $=2 \mu \mathrm{m}$. (G) Paramarteilia canceri infecting the testicular follicles

1085 (arrow). Edible crab. H\&E. Scale bar $=10 \mu \mathrm{m}$. Inset: ISH labelling of $P$.canceri infecting the

1086 testicular follicles. Edible crab. Scale bar $=10 \mu \mathrm{m}$. (H) TEM of $P$. canceri within the testicular

1087 follicles. Parasite appears to be attached to the epithelium of the testicular follicle (arrow). Edible

1088 crab. Scale bar $=2 \mu \mathrm{m}$.

1089

1090 
Table 1. Review of paramyxids known prior to this study for which sequence data and/or microscopy evidence unambiguously identifies the lineage identity to at least genus level. Where shown in bold, GenBank accession numbers are 18S sequences used in our phylogenetic analyses (Fig. 1). Where not in bold, sequences are either identical duplicates, or a different region (Internal Transcribed Spacer 1 (ITS1), Intergenic Spacer (IGS) rDNA) from the same lineage, or in a few cases unambiguously identified (e.g. confirmed by subsequent sequencing). Bold geographical locations/citations represent findings confirmed by sequence data. Underlined entries indicate data generated in this study.

\begin{tabular}{|c|c|c|c|c|c|}
\hline Parasite genus & Species & Host & Geographical Location & Citation & GenBank Accession \\
\hline \multirow[t]{2}{*}{ Paramyxa } & Paramyxa nephtys & $\begin{array}{l}\text { Nephtys caeca } \\
\text { Environmental (water) }\end{array}$ & $\begin{array}{l}\text { Øresund, Denmark } \\
\text { Portland, UK } \\
\text { Tamar estuary, UK }\end{array}$ & $\begin{array}{l}\text { Larsson and Koie, } \\
2005 \\
\text { Ward et al., 2016 }\end{array}$ & KX259324 (partial 18S) \\
\hline & $\begin{array}{l}\text { Paramyxa paradoxa } \\
\text { Paramyxa sp. } \\
\frac{\text { 'Paramyxa' sp. }}{\text { 'Paramyxa' sp. }} \\
\text { 'Paramyxa'sp. }\end{array}$ & $\begin{array}{l}\text { Poecilochaetus serpens } \\
\text { Mytilus edulis } \\
\text { Environmental (water) } \\
\text { Ostrea edulis } \\
\text { Mytilus edulis } \\
\text { Ostrea edulis }\end{array}$ & $\begin{array}{l}\text { Banyuls-sur-Mer, France } \\
\text { Tamar estuary, UK } \\
\frac{\text { Malaysian Borneo }}{\text { Tamar estuary, UK }} \\
\text { Tamar estuary, UK }\end{array}$ & $\begin{array}{l}\text { Chatton } 1911 \\
\text { Ward et al., } 2016 \\
\text { Ward et al., 2016 } \\
\text { Ward et al., 2016 } \\
\text { Ward et al., 2016 }\end{array}$ & $\begin{array}{l}\frac{\text { KX259326 (partial 18S) }}{\text { KX259325 (partial 18S) }} \\
\text { KX259323 (partial 18S) } \\
\text { KN259327 (partial 18S) }\end{array}$ \\
\hline \multirow[t]{3}{*}{ Paramarteilia } & $\begin{array}{l}\text { Paramarteilia } \\
\text { orchestiae }\end{array}$ & Orchestia gammarellus & $\begin{array}{l}\text { Guernsey, UK } \\
\text { Weymouth and Portland, } \\
\text { UK } \\
\text { South Kimmeridge Bay, UK } \\
\text { Taulé-Penzé, France } \\
\text { Dale, UK } \\
\text { Wevmouth. UK }\end{array}$ & $\begin{array}{l}\text { Ginsburger-Vogel et } \\
\text { al., } 1976 \\
\text { Ward et al., } 2016 \\
\end{array}$ & \\
\hline & & $\begin{array}{l}\text { Echinogammarus } \\
\text { marinus } \\
\text { Environmental (mollusc } \\
\text { and crustacean } \\
\text { incubations) }\end{array}$ & $\begin{array}{l}\text { Inverkeithing, UK } \\
\text { Portsmouth, UK } \\
\text { Weymouth and Tamar } \\
\text { estuary, UK } \\
\end{array}$ & $\begin{array}{l}\text { Short et al., 2012a } \\
\text { Ward et al., } 2016\end{array}$ & JQ673484 (partial 18S) \\
\hline & Paramarteilia sp. & $\begin{array}{l}\text { Environmental (Mytilus } \\
\text { edulis incubation) }\end{array}$ & Tamar estuary, UK & Ward et al., 2016 & KX259320 (partial 18S) \\
\hline Marteilioides & $\begin{array}{l}\text { Marteilioides branchialis } \\
\text { Marteilioides } \\
\text { chungmuensis }\end{array}$ & Saccostrea glomerata & $\begin{array}{l}\text { New South Wales, Australia } \\
\text { Okayama, Japan } \\
\text { Seomijn River, South } \\
\text { Korea }\end{array}$ & $\begin{array}{l}\text { Anderson and Lester, } \\
1992 \\
\text { ltoh et al., } \mathbf{2 0 0 3} \\
\text { Yanin et al., } 2013\end{array}$ & $\begin{array}{l}\text { AB110795 (18S) } \\
\text { GU132548(18S) }\end{array}$ \\
\hline
\end{tabular}




\section{ACO \\ Marteilioides sp. \\ Crassostrea gigas \\ Crassostrea nippona \\ Ruditapes philippinarum}

Marteilia

Marteilia christenseni

Marteilia cochillia

Marteilia lengehi

Marteilia octospora

Marteilia refringens
Scrobicularia piperata

Cerastoderma edule

Saccostrea cucullata

Solen marginatus

Ostrea edulis

Mytilus edulis

Mytilus galloprovincialis

Ostrea stentina

Chamelea gallina

Solen marginatus

Ruditapes decussatus

Xenostrobus securis

Paracartia grani

Paracartia latisetosa
Tongyoung, South Korea

Japan

Hadong/Namhae, South

Korea

Tongyoung, South Korea

Marennes-Oléron, France

Ebro Delta, Catalonia,

Spain

Ria de Arousa, Galicia,

\section{Spain}

Bandar-Lengeh, Iran

Qeshm, Iran

Ría de Arousa, Galicia,

\section{Spain}

Bassin d'Arcachon, France

Île d'Oléron, France

Corsica, France

Brittany, France

Brittany, France

Tamar estuary, UK

Venice, Italy

Galicia, Spain

Istrian Peninsula, Croatia

Ebro Delta, Catalonia,

Spain

Campania, Italy

Corsica, France

Slovene Adriatic Sea,

\section{Slovenia}

Monastir Bay, Tunisia

Bay of Palma, Mallorca,

Spain

Huelva, Spain

Thau Lagoon, France

Galicia, Spain

Marennes-Oléron, France

Diana Lagoon, Corsica,

France
Yanin et al., 2013

Itoh et al., 2004

Lee et al., 2001

Yanin et al., 2013

GU132457(18S)

Comps et al., 1983

Carrasco et al., 2013 KF314809 (IGS)

Villalba et al., 2014

KF278722 (18S)

Comps, 1976

Ruiz et al., 2016

KU641125 (partial 18S) KU641126 (ITS1)

Grizel et al., 1974

Berthe et al., 2000

Pichot, 2002

Comps et al., 1975

Berthe et al., 2000

Bignell et al., 2011

Comps et al., 1982

Villalba et al., 1993

Zrncic et al., 2001

Carrasco et al., 2008

Carella et al., 2010

Arzul et al., 2014

Gombac et al., 2014

AJ250699 (18S)

AJ250699 (18S)

Elgharsalli et al.,

\section{3}

Lopes-Flores et al., 2008a

Lopes-Flores et al., 2008b

Boyer et al., 2013

Pascual et al., 2010

Audemard et al.,

2001

Arzul et al., 2014
AB534169-70 (ITS1)

JQ898012-14 (ITS1)

JX119018-22 (IGS)

AM292652 (IGS)

AM748037-41 (IGS) 
Marteilia sydneyi

Marteilia sp. MC

Marteilia sp.

Marteilia sp.

Eomarteilia

Eomarteilia granula

PARAM-1

PARAM-2
(Crassostrea gigas)

(Crassostrea

corteziensis)

(Acartia clausi)

(Acartia discaudata)

(Acartia italica)

(Euterpina acutifrons)

(Oithona sp.)

Environmental (water, sediment)

Saccostrea glomerata

Sonora, Gulf of California,

Mexico

Ebro Delta, Catalonia,

Spain

\section{Tamar estuary, UK}

Queensland, Australia

Queensland, Australia

Pimpama River,

Queensland, Australia

Nephtys australiensis

Ruditapes philippinarum

Hawkesbury River, NSW, Australia

South Korea

Mytilus edulis

Environmental (Penaeus

hatchery tank water)

Ruditapes philippinarum

Environmental (water)

Environmental (water)

\section{China}

Malaysian Borneo

Kanagawa, Japan

Gulf coast, Florida, USA

Cariaco Basin, Venezuela
Grijalva-Chon et al., 2015

Carrasco et al., 2007b

JQ066723-4 (IGS) JQ066725-6 (IGS)

Environmental (water) $\quad$ Gulf coast, Florida, USA

\section{Ward et al., 2016}

Perkins and Wolf,

1976

Kleeman and Adlard

2000

Itoh et al., 2014

Adlard and Nolan,

\section{5}

Kang et al.,

Wang et al., 2012

Ward et al., 2016

Itoh et al., 2014

Ward et al., 2016

Edgcomb et al., 2011

AF159248 (ITS1)

AB823742 (18S)

AB823743 (18S)

KX259319

KX259318 (partial 18S)

AB856587 (18S)

KZ259322 (Partial 18S)

Ward et al., 2016

KX259321 (Partial 18S) (unpublished) 


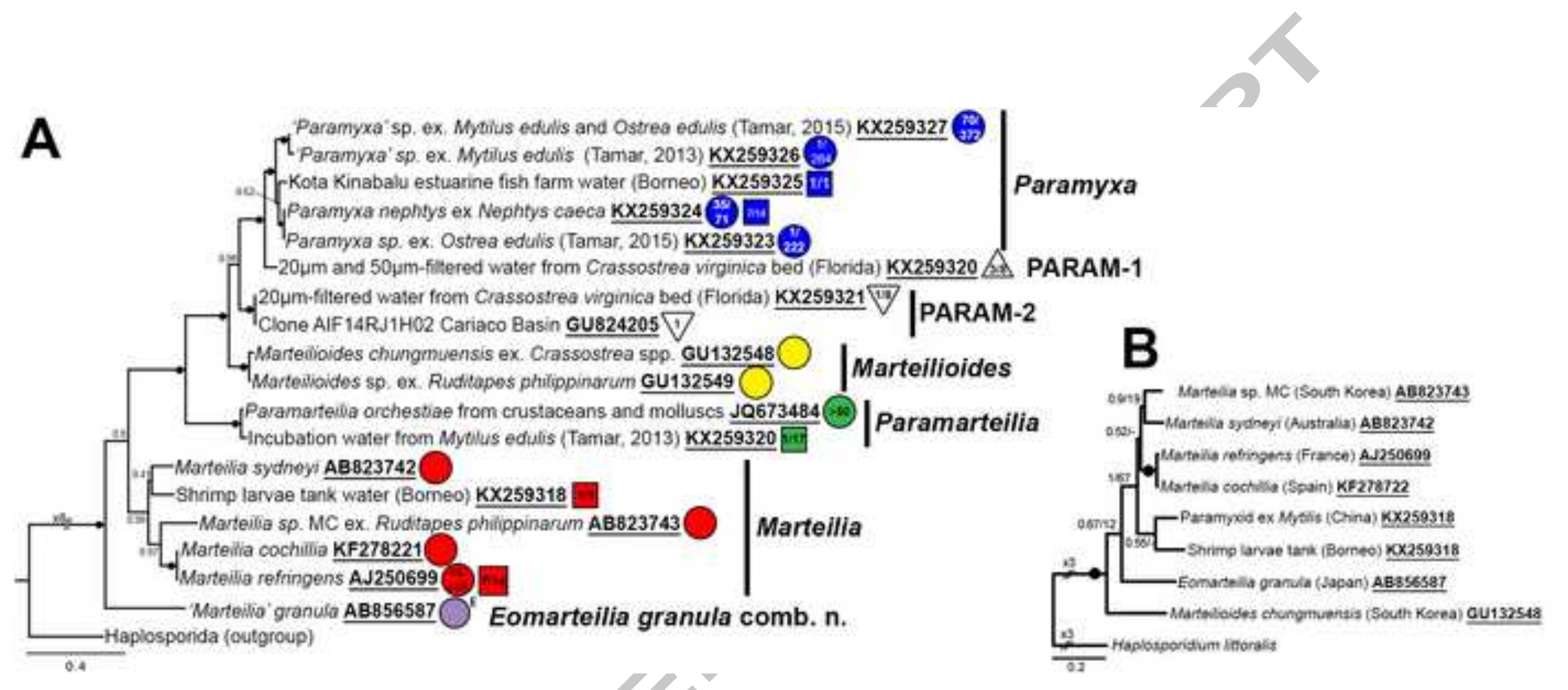




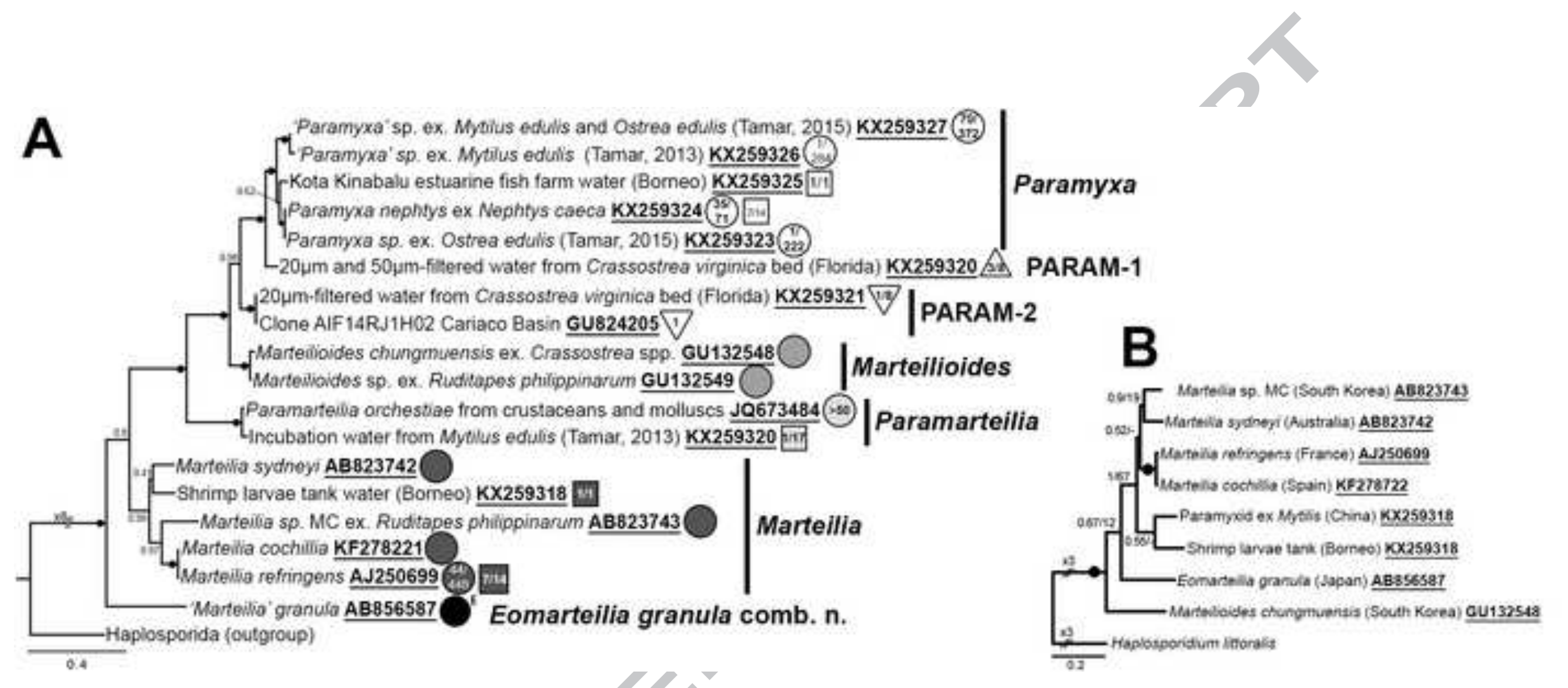




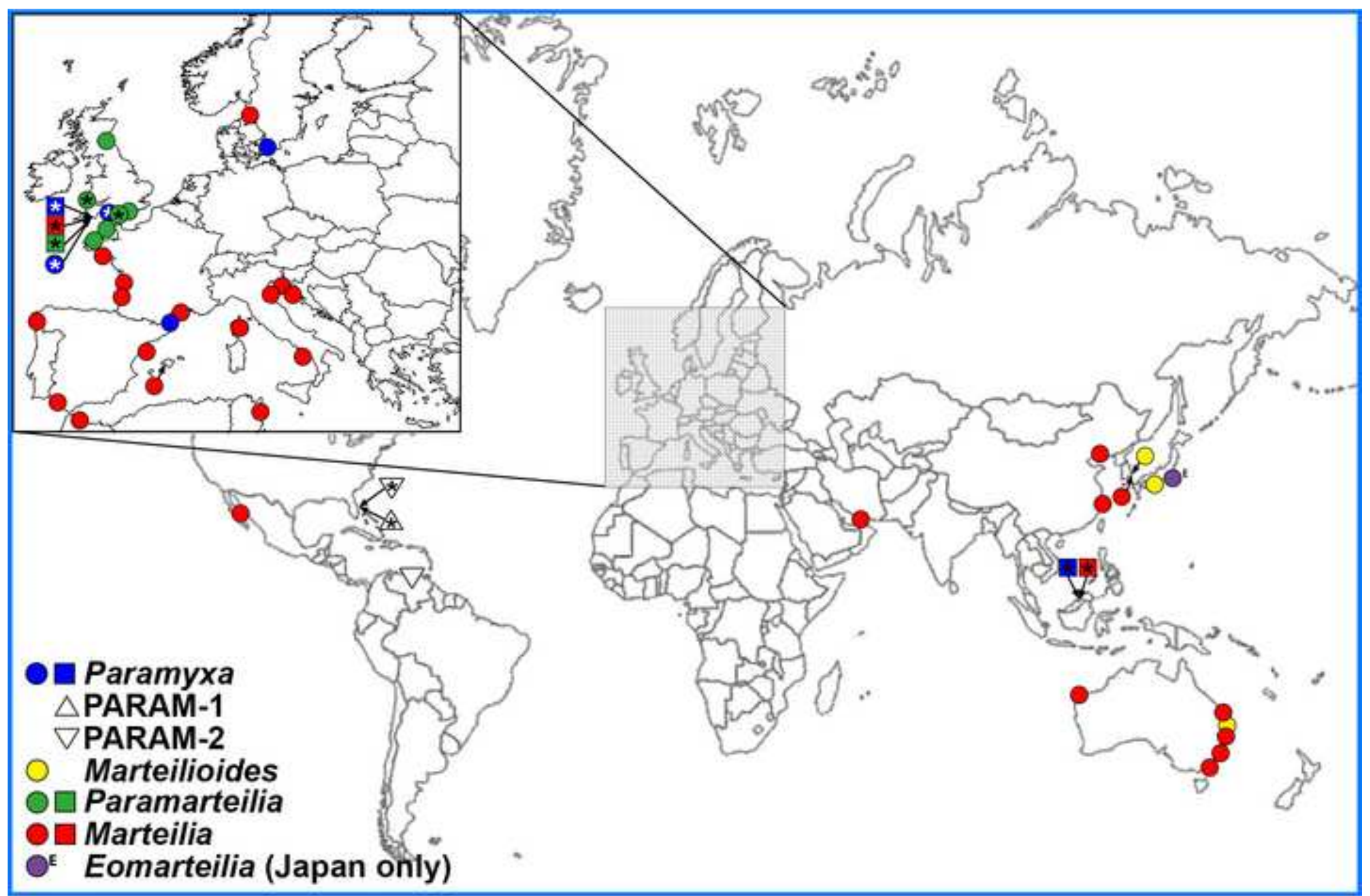


ACCEPTED MANUSCRIPT

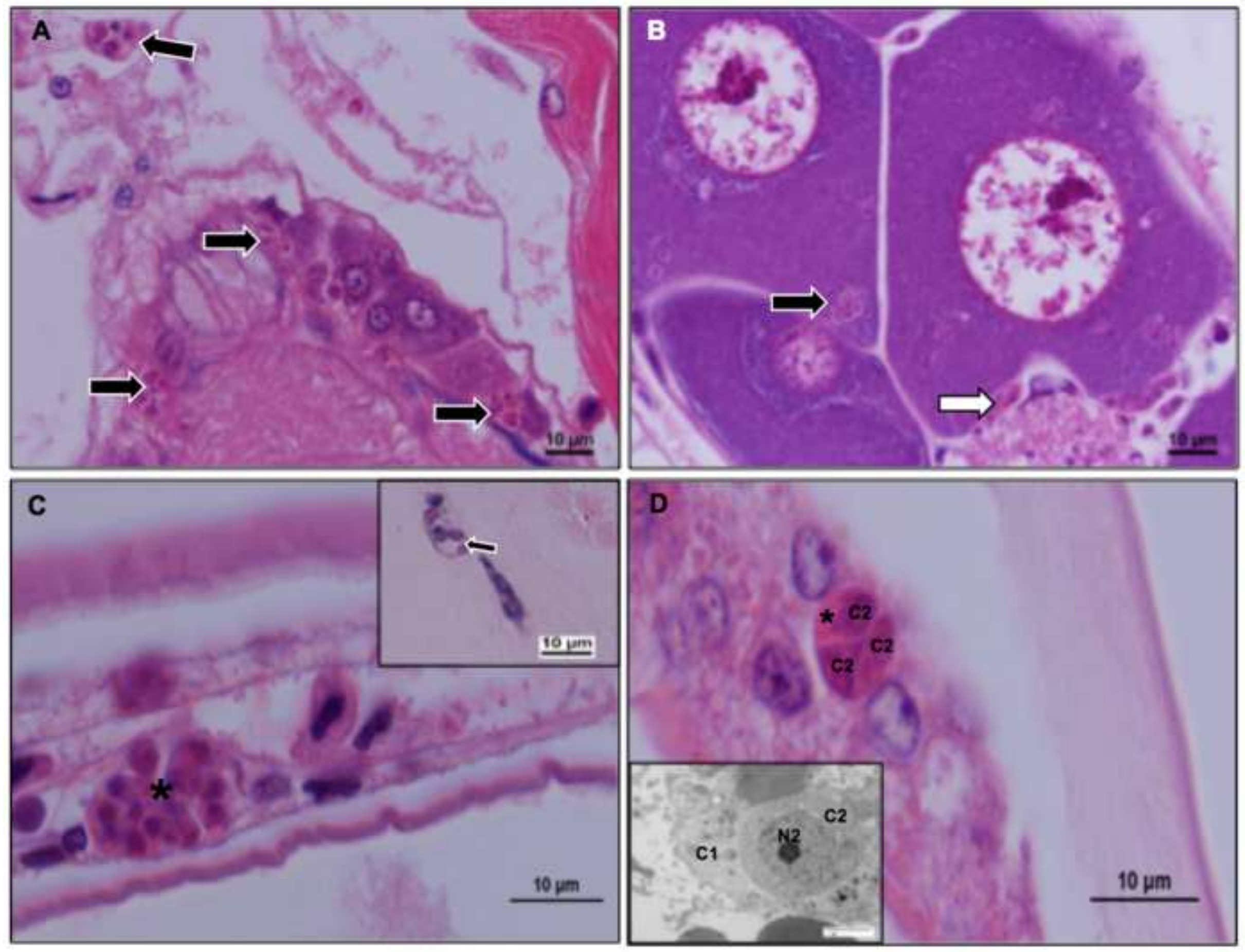

$\sim$ $\nabla$ 
ACCEPTED MANUSCRIPT
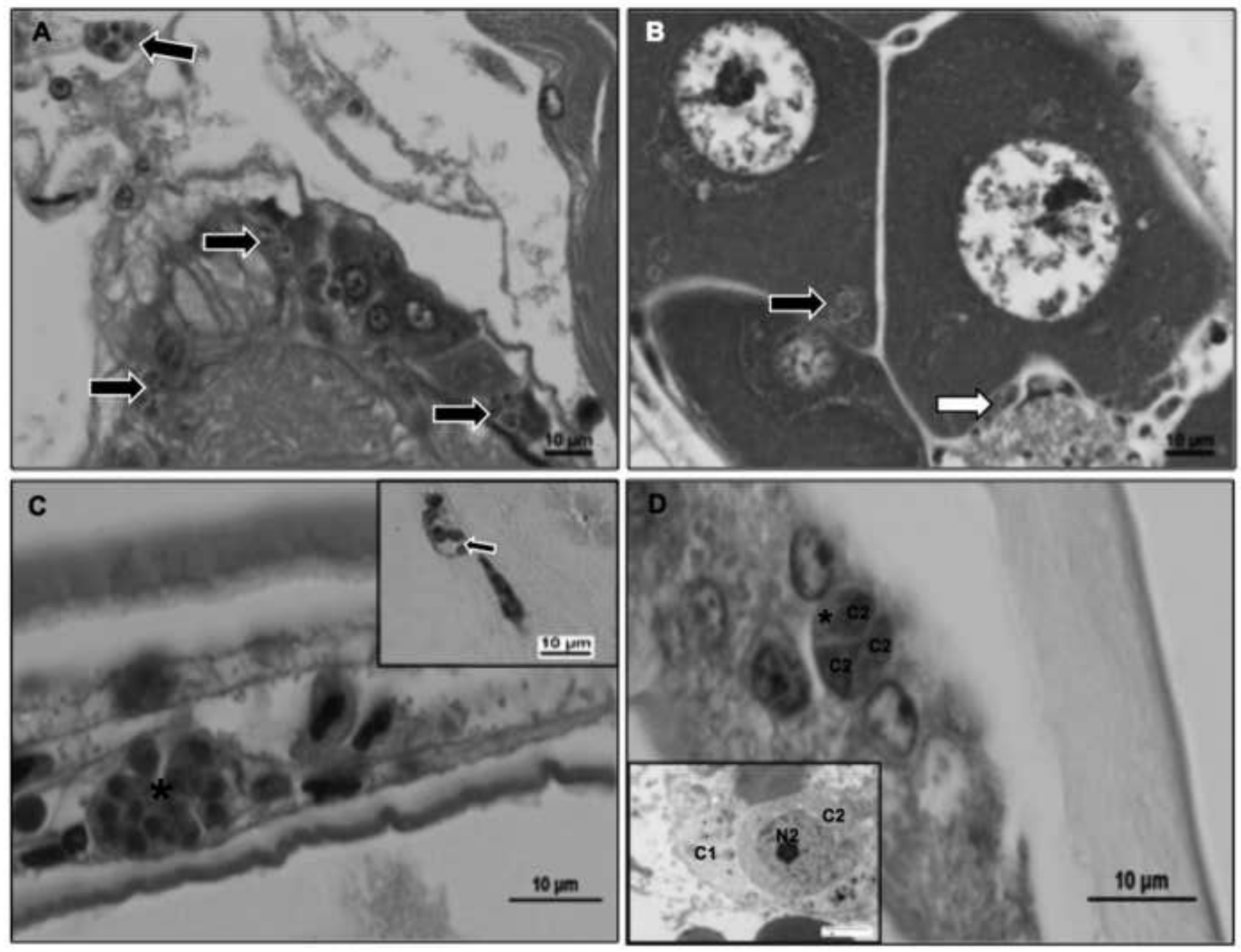

r $\nabla$ 

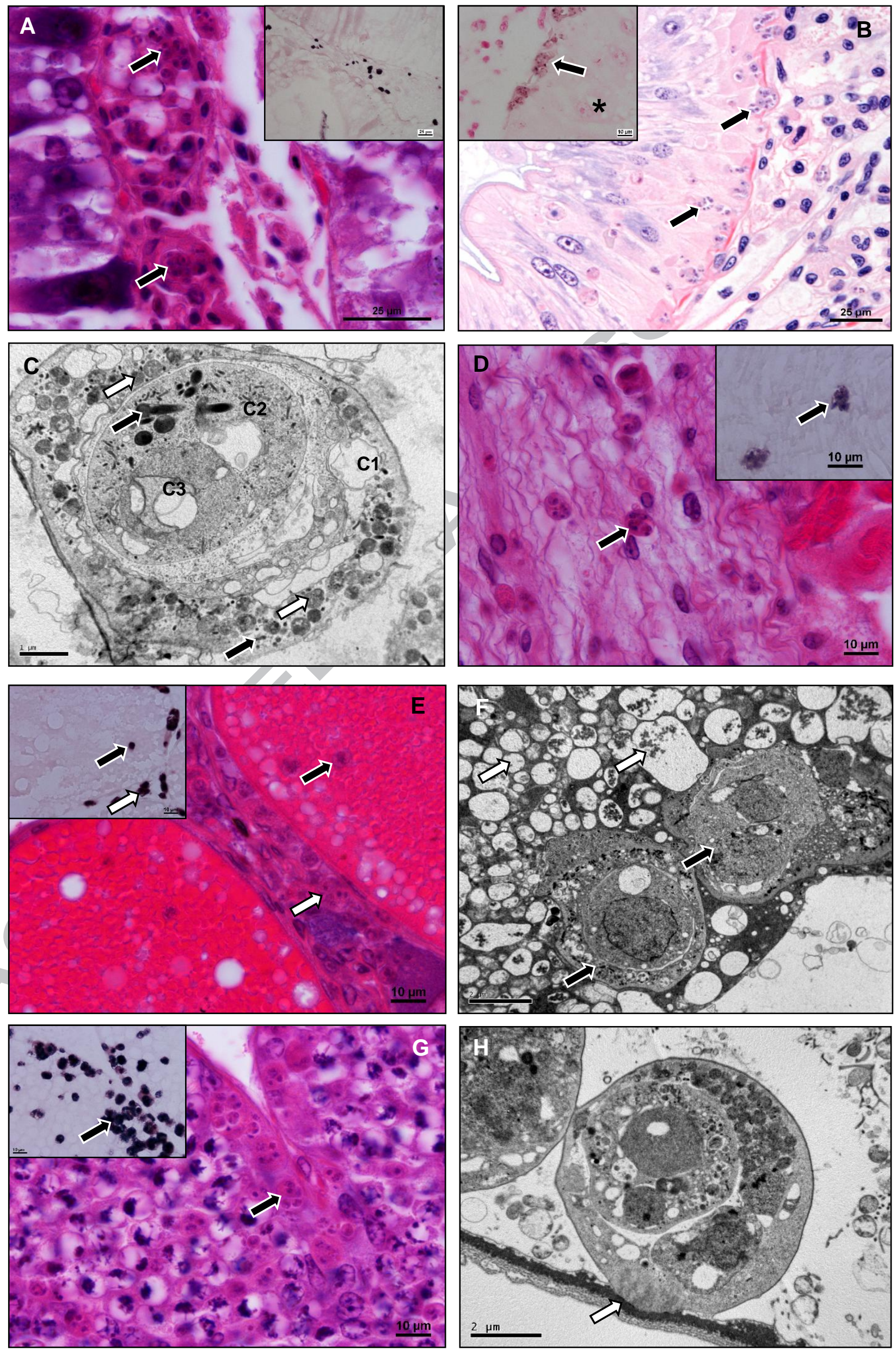

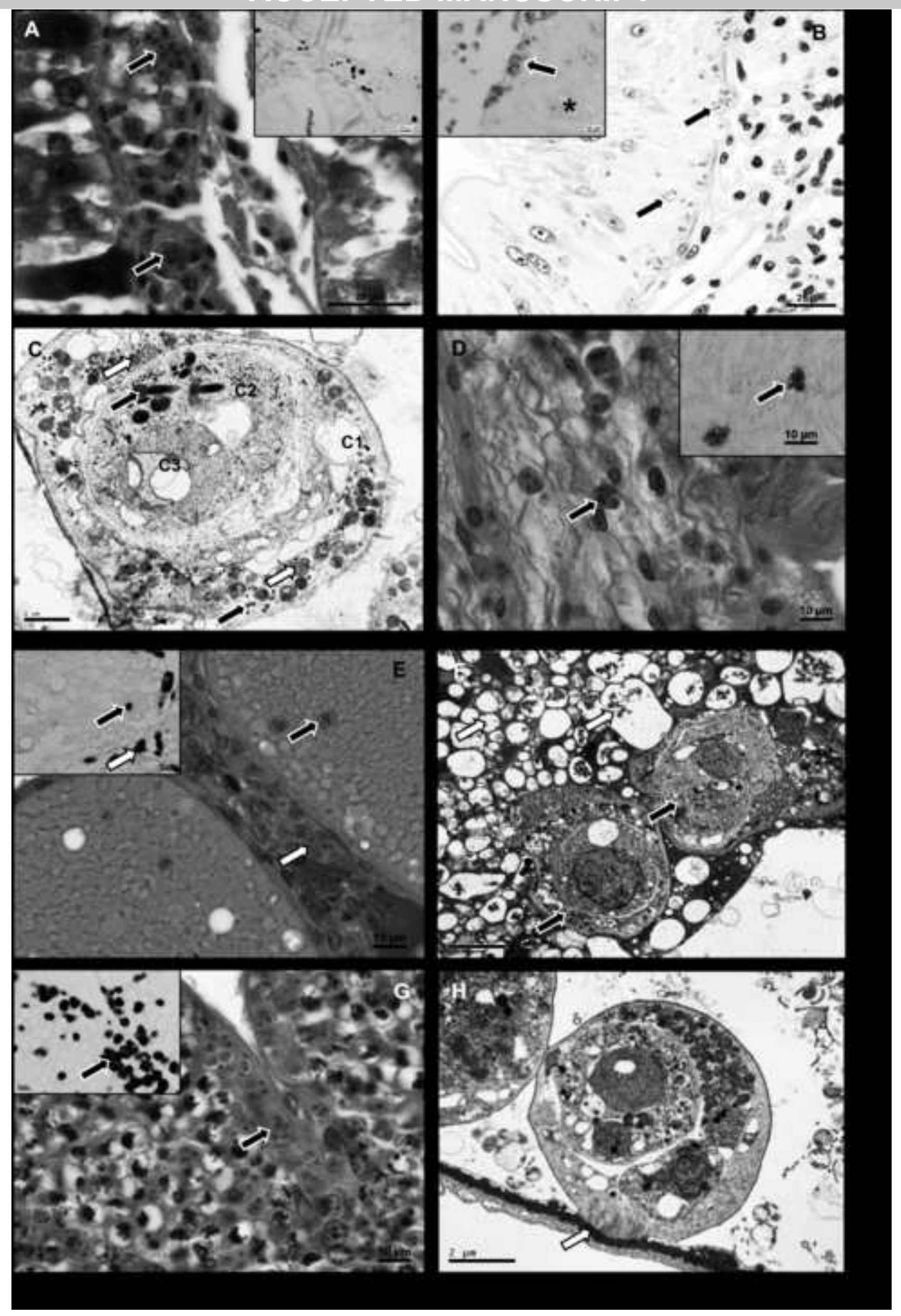

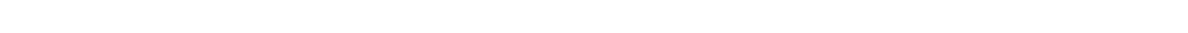

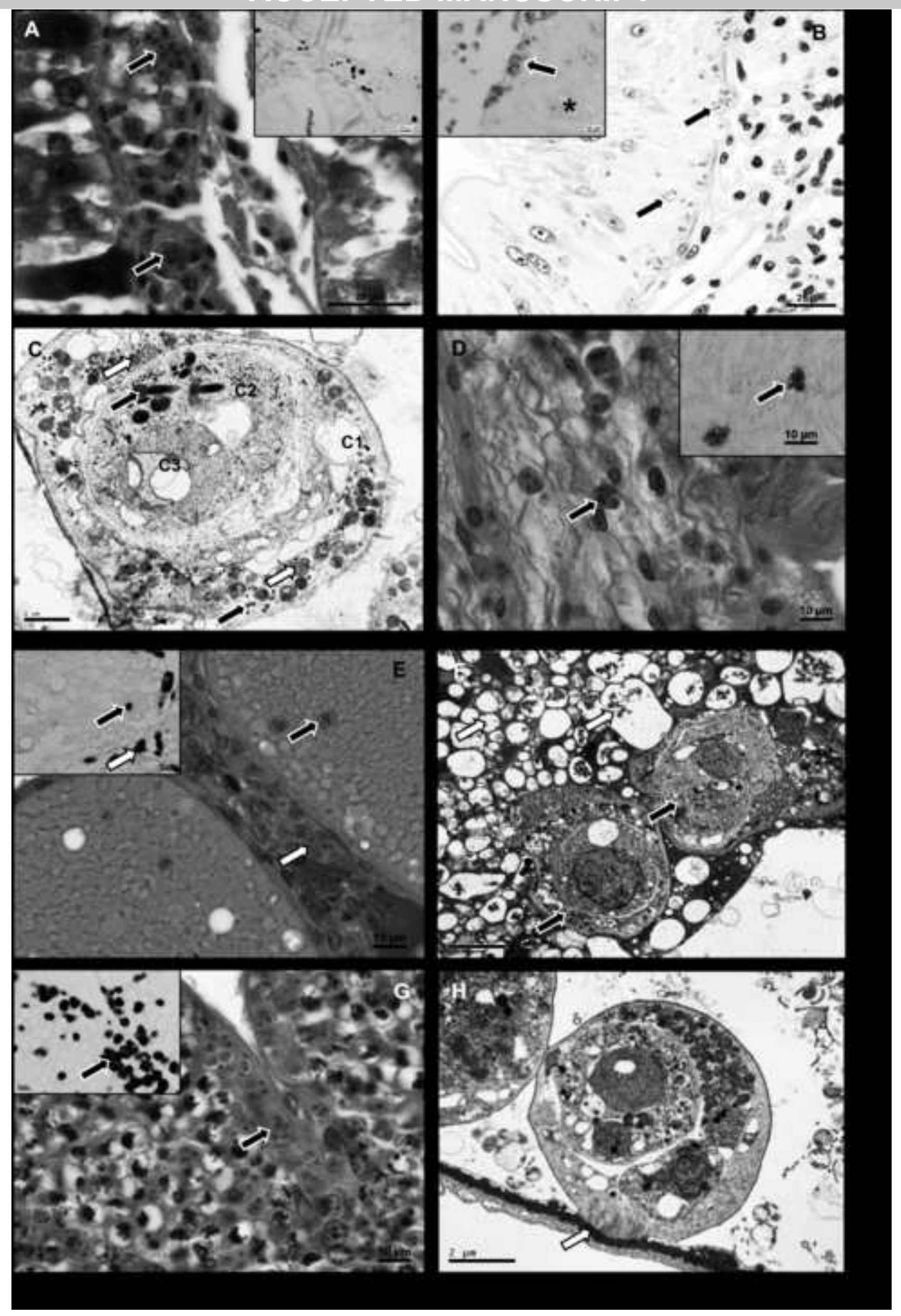




\section{PARAMYXIDA}

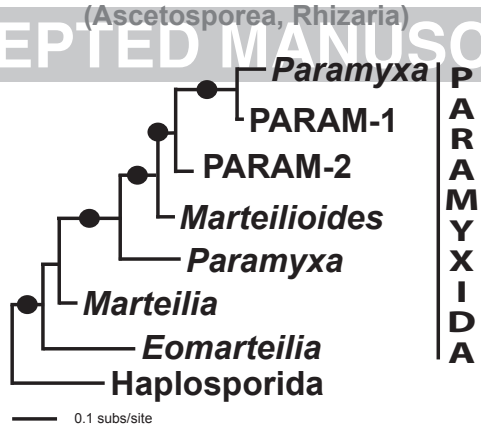




\section{Highlights}

- Phylogeny of the Paramyxida confirms five genera: Marteilia, Eomarteilia, Paramarteilia, Paramyxa, and Marteilioides

- Specific primers and environmental DNA approaches reveal novel diversity and distribution of paramyxids

- Paramyxids are parasites of diverse marine molluscs, crustaceans and polychaetes

- Paramyxa nephtys was identified in Nephtys caeca and the first $18 \mathrm{~S}$ rDNA sequence reported for this genus

- Paramarteilia was identified in amphipods Orchestia, Echinogammarus, and crabs Cancer, Carcinus, Maja 